Prepared in cooperation with the Massachusetts Office of Coastal Zone Management

Sea-Floor Texture and Physiographic Zones of the Inner Continental Shelf From Salisbury to Nahant, Massachusetts, Including the Merrimack Embayment and Western Massachusetts Bay
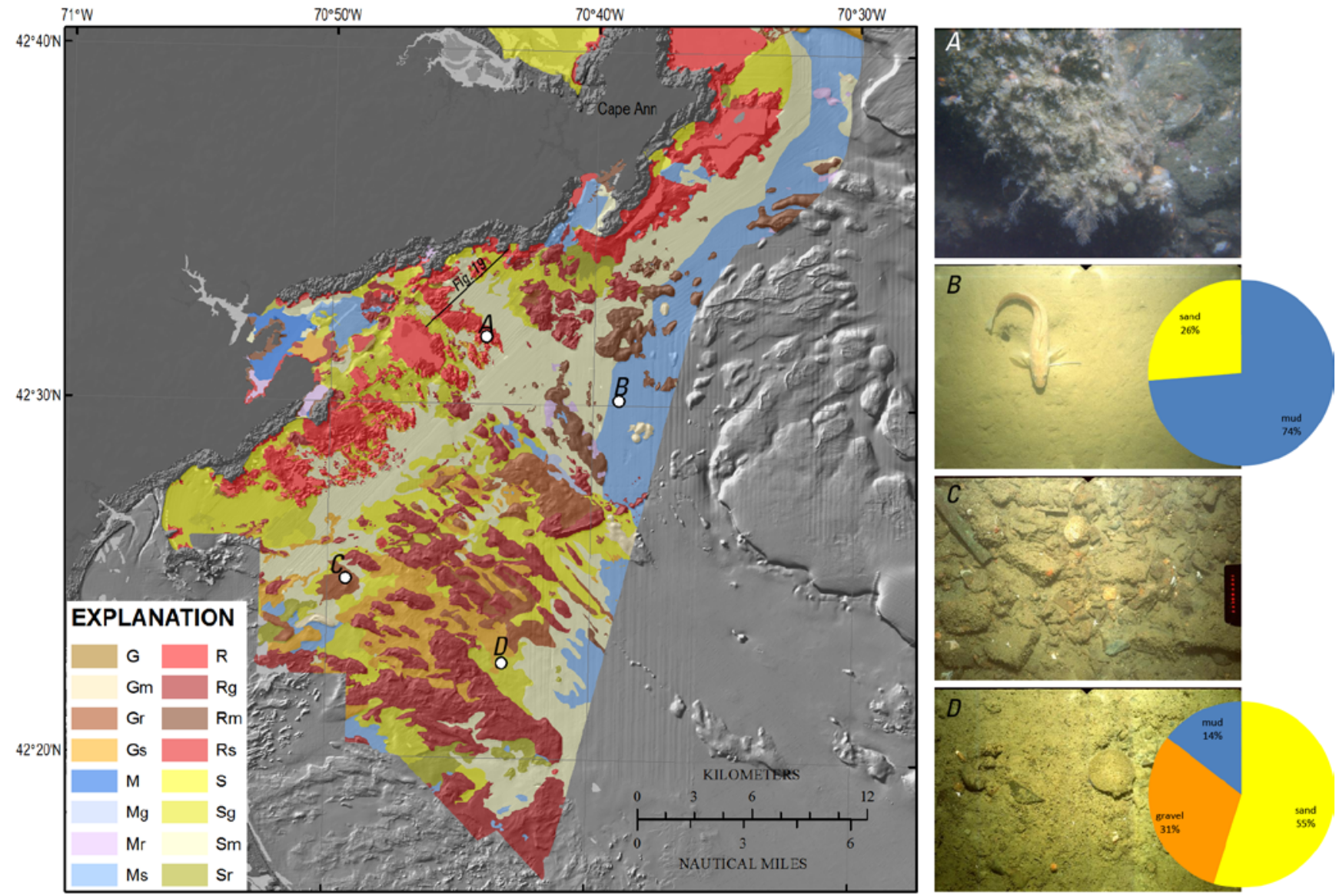

Base from Massachusetts Office of Geographic Information

Universal Transverse Mercator Projection, Zone 19N

Open-File Report 2015-1153

U.S. Department of the Interior

U.S. Geological Survey 



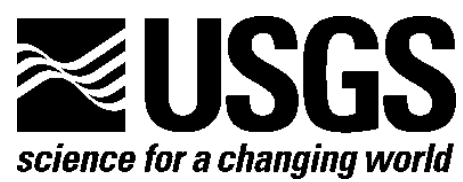

Prepared in cooperation with the Massachusetts Office of Coastal Zone Management

\section{Sea-Floor Texture and Physiographic Zones of the Inner Continental Shelf From Salisbury to Nahant, Massachusetts, Including the Merrimack Embayment and Western Massachusetts Bay}

By Elizabeth A. Pendleton, Walter A. Barnhardt, Wayne E. Baldwin, David S. Foster, William C. Schwab, Brian D. Andrews, and Seth D. Ackerman

Open-File Report 2015-1153

U.S. Department of the Interior

U.S. Geological Survey 


\section{U.S. Department of the Interior \\ SALLY JEWELL, Secretary}

\section{U.S. Geological Survey \\ Suzette M. Kimball, Acting Director}

U.S. Geological Survey, Reston, Virginia: 2015

For more information on the USGS—-the Federal source for science about the Earth, its natural and living resources, natural hazards, and the environment-visit http://www.usgs.gov/ or call 1-888-ASK-USGS (1-888-275-8747).

For an overview of USGS information products, including maps, imagery, and publications, visit http://www.usgs.gov/pubprod/.

Any use of trade, firm, or product names is for descriptive purposes only and does not imply endorsement by the U.S. Government.

Although this information product, for the most part, is in the public domain, it also may contain copyrighted materials as noted in the text. Permission to reproduce copyrighted items must be secured from the copyright owner.

Suggested citation:

Pendleton, E.A., Barnhardt, W.A., Baldwin, W.E., Foster, D.S., Schwab, W.C., Andrews, B.D., and Ackerman, S.D., 2015, Sea-floor texture and physiographic zones of the inner continental shelf from Salisbury to Nahant, Massachusetts, including the Merrimack Embayment and Western Massachusetts Bay: U.S. Geological Survey Open-File Report 2015-1153, 36 p., 1 appendix, http://dx.doi.org/10.3133/ofr20151153. 


\section{Acknowledgments}

This research was done in cooperation with the Massachusetts Office of Coastal Zone Management. This manuscript benefited from reviews by Brad Butman, VeeAnn Cross, Jonas Casey-Williams, Nancy Stamm, and Jane Denny, all of the U.S. Geological Survey. 


\section{Contents}

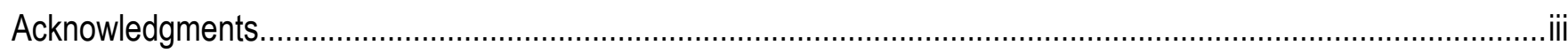

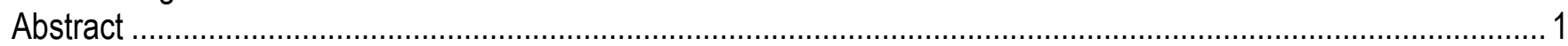

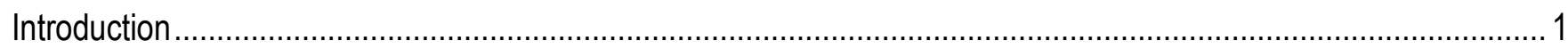

Purpose and Scope

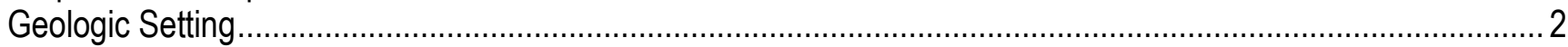

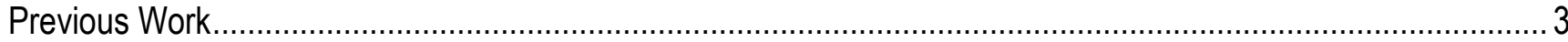

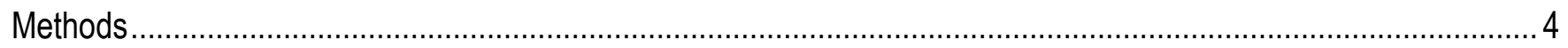

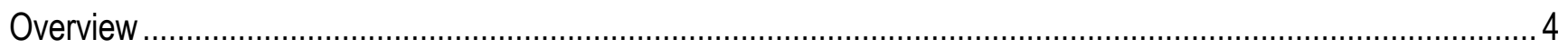

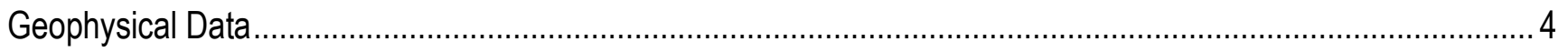

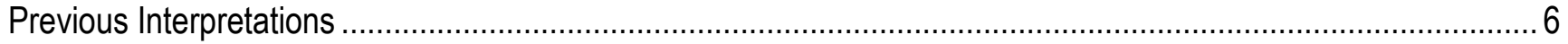

Sediment Samples and Sediment Texture Classification Schemes .......................................................... 6

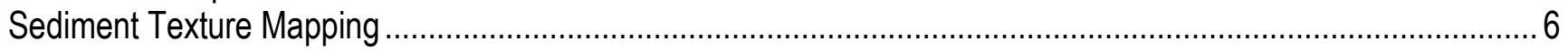

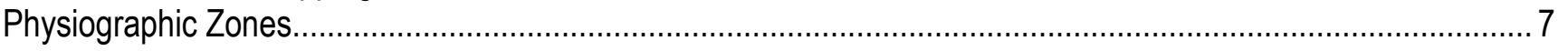

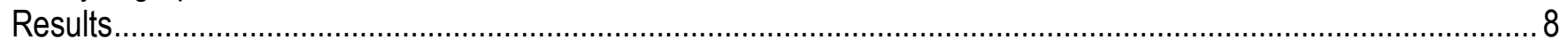

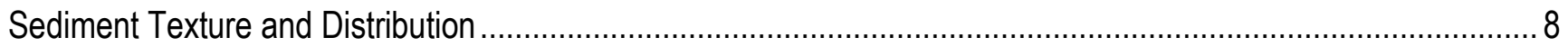

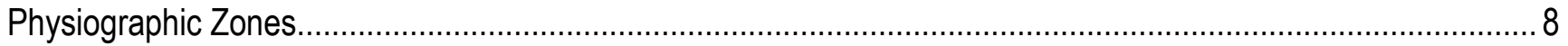

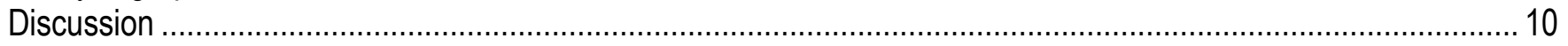

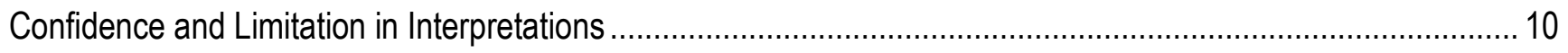

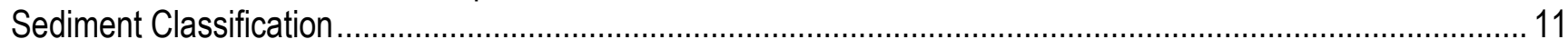

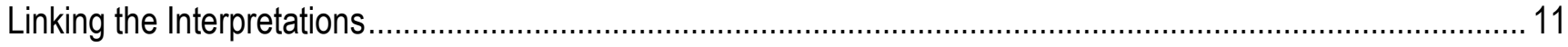

Coastal Evolution and Modern Processes on the Inner Continental Shelf .................................................... 12

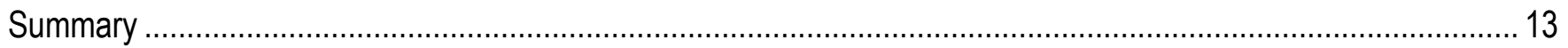

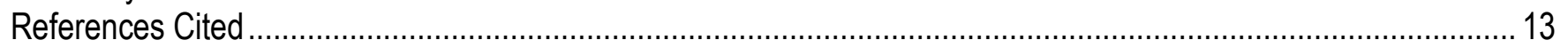

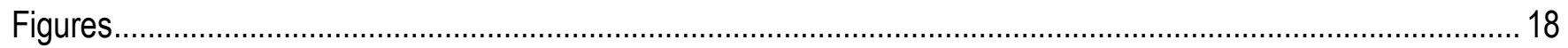

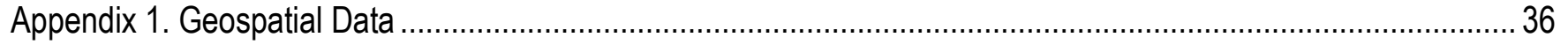

\section{Figures}

1. Location map of the study area that extends from offshore of Hull to Salisbury, Massachusetts, near the New Hampshire border................................................................................................ 18

2. Sea-level curve for the southern Merrimack Embayment from Barnhardt and others (2009), modified after Oldale and others (1993) ............................................................................................... 19

3. A composite backscatter image of the study area at 10-meter resolution, created from a series of published backscatter images..

4. A digital elevation model, produced from swath-interferometric and multibeam bathymetry and lidar at 30 -meter resolution.

5. Generalized geologic map created by combining previously published stratigraphic interpretations within the study area and new interpretation for western Massachusetts Bay.....

6. Seismic stratigraphic units interpreted by Oldale and Bick (1987), Oldale and Wommack (1987), and Hein and others (2013).

7. Bottom photographs and sediment samples collected within the study area and used to aid interpretations. 
8. Barnhardt and others (1998) bottom-type classification based on four basic sediment units:

rock, gravel, sand, and mud

9. Sediment texture polygons were created in ArcGIS by using $A$, backscatter data; $B$, hillshaded relief imagery; $C$, rugosity; $D$, slope; and $E$, pseudocolored multibeam backscatter intensity 26

10. Sediment texture and distribution data were mapped qualitatively in ArcGIS by using a hierarchical methodology

11. The distribution of sediment textures within the study area from Nahant, Massachusetts, to New Hampshire..... 28

12. Inner continental shelf sediment textures between Cape Ann and New Hampshire with bottom photographs $A-D$ showing sediment texture as defined in select locations

13. Inner continental shelf sediment textures within western Massachusetts Bay with bottom photographs $A-D$ showing sediment texture as it is defined in select locations 30

14. Pie chart showing the percentage of each primary sediment unit within the study area 31

15. The distribution of physiographic zones within the study area from Nahant to Salisbury, including western Massachusetts Bay 32

16. Sediment texture regions in the study area and confidence values for data interpretation 33

17. A chirp seismic reflection profile across the inner shelf from near the southern end of Plum Island, Massachusetts, to approximately 70 meters water depth 34

18. Figure showing bathymetry, backscatter with physiographic zone boundaries, and bottom photographs along a seismic reflection profile

\section{Tables}

1. Previously published studies of sea-floor geology in the southern Merrimack Embayment and western Massachusetts Bay.

2. Data sources for the digital elevation model, backscatter mosaic, and seismic-reflection profile interpretations. 


\section{Conversion Factors}

SI to Inch/Pound

\begin{tabular}{lll}
\hline \multicolumn{1}{c}{ Multiply } & \multicolumn{1}{c}{ By } & \multicolumn{1}{c}{ To obtain } \\
\hline millimeter $(\mathrm{mm})$ & 0.03937 & inch (in.) \\
meter $(\mathrm{m})$ & 3.281 & foot (ft) \\
kilometer $(\mathrm{km})$ & 0.6214 & mile (mi) \\
kilometer $(\mathrm{km})$ & 0.5400 & mile, nautical $(\mathrm{nmi})$ \\
meter $(\mathrm{m})$ & 1.094 & yard $(\mathrm{yd})$ \\
\hline & Area & \\
\hline square meter $\left(\mathrm{m}^{2}\right)$ & 10.76 & square foot $\left(\mathrm{ft}^{2}\right)$ \\
square kilometers $\left(\mathrm{km}^{2}\right)$ & 0.386102159 & square miles $\left(\mathrm{mi}^{2}\right)$ \\
\hline
\end{tabular}

\section{Datum}

Vertical coordinate information is referenced to North American Vertical Datum of 1988 (NAVD 88).

Elevation, as used in this report, refers to distance above the vertical datum.

Horizontal coordinate information is referenced to the World Geodetic System of 1984 (WGS84) in a Geographic Coordinate System.

\section{Supplemental Information}

Particle size in phi units may be converted to millimeters $(\mathrm{mm})$ as $\mathrm{mm}=2^{- \text {phi }}$.

\section{Abbreviations}

$\mathrm{BP}$

before present

CZM

Massachusetts Office of Coastal Zone Management

DEM

digital elevation model

GIS

geographic information system 


\title{
Sea-Floor Texture and Physiographic Zones of the Inner Continental Shelf From Salisbury to Nahant, Massachusetts, Including the Merrimack Embayment and Western Massachusetts Bay
}

By Elizabeth A. Pendleton, Walter A. Barnhardt, Wayne E. Baldwin, David S. Foster, William C. Schwab, Brian D. Andrews, and Seth D. Ackerman

\begin{abstract}
A series of maps that describe the distribution and texture of sea-floor sediments and physiographic zones of Massachusetts State waters from Nahant to Salisbury, Massachusetts, including western Massachusetts Bay, have been produced by using high-resolution geophysical data (interferometric and multibeam swath bathymetry, lidar bathymetry, backscatter intensity, and seismic reflection profiles), sediment samples, and bottom photographs. These interpretations are intended to aid statewide efforts to inventory and manage coastal and marine resources, link with existing data interpretations, and provide information for research focused on coastal evolution and environmental change. Marine geologic mapping of the inner continental shelf of Massachusetts is a statewide cooperative effort of the U.S. Geological Survey and the Massachusetts Office of Coastal Zone Management.
\end{abstract}

\section{Introduction}

\section{Purpose and Scope}

This report describes sea-floor texture and distribution and physiographic zones of the Massachusetts coastal zone between Salisbury and Nahant, Massachusetts, including the southern Merrimack Embayment and western Massachusetts Bay (fig. 1). This report supplements and expands interpretations in the nearshore zone of Nahant to Gloucester, Mass. (Barnhardt and others, 2006), and the southern Merrimack Embayment (Barnhardt and others, 2009; Hein and others, 2013).

Interpretations are provided as geospatial data layers in Esri Inc. ArcGIS formats (appendix 1). This research was part of a cooperative sea-floor mapping program (http://woodshole.er.usgs.gov/projectpages/coastal_mass/) between the U.S. Geological Survey and the Massachusetts Office of Coastal Zone Management (CZM). This cooperative effort fosters data collection and the production of interpretive geospatial datasets that can be used by managers and scientists to delineate marine resources, assess environmental change, inventory marine habitats, and support research concerning sea-level change, sediment supply, and coastal evolution (Massachusetts Office of Coastal Zone Management, 2015).

The maps presented in this report are based on interpretation of high-resolution seismicreflection data, swath bathymetry, acoustic backscatter, bottom photographs, and sediment samples 
collected within nearshore regions (less than about 30-meter [m] water depth) from Nahant to Salisbury (Barnhardt and others 2006, 2009); lidar observations in water less than approximately $3 \mathrm{~m}$ deep (Joint Airborne Lidar Bathymetry Technical Center of Expertise and U.S. Army Corps of Engineers, 2008); bottom photographs and texture data (Gutierrez and others, 2000) and multibeam and backscatter data collected around Cape Ann and western Massachusetts Bay in water depths greater than $30 \mathrm{~m}$ (Butman and others, 2007); and sediment texture databases (Ford and Voss, 2010; McMullen and others, 2011) modified by the CZM (Emily Huntley, CZM, unpub. data, 2012). These data were used to create a statewide sediment texture distribution map and physiographic zone dataset wherever high-resolution geophysical data exist. This report extends the previous nearshore interpretations of physiographic zones to the State offshore boundary (approximately 3 miles) and presents a new sea-floor sediment texture map for the Massachusetts coastal zone from Nahant to Salisbury, including western Massachusetts Bay and the southern Merrimack Embayment.

\section{Geologic Setting}

The coastal zone from Nahant to Salisbury consists of three distinct geomorphic segments. The first coastal segment, which extends northeast from Nahant to Gloucester (fig. 1), is characterized by numerous rocky headlands and islands, small pocket beaches, and narrow harbors. The second coastal segment encompasses the entire Cape Ann promontory from Gloucester to the Annisquam Harbor and separates the southern Merrimack Embayment from Massachusetts Bay. The third coastal segment extends from Annisquam Harbor to the New Hampshire border and consists of a chain of sandy barrier islands separated by tidal inlets.

Granitic bedrock near Nahant is primarily Precambrian, but farther north at Cape Ann, granites are generally Ordovician to Devonian (Cameron and Naylor, 1976; Zen and others, 1983). Offshore, bedrock from Hull to Salisbury is locally overlain by Triassic sedimentary units or Cretaceous- and Tertiary-age coastal plain deposits (Oldale and others, 1983). Pleistocene glacial deposits and Holocene postglacial beach and marsh deposits unconformably overlie pre-Quaternary age units. Bedrock exposures are uncommon along the coast and on the inner shelf between Annisquam Harbor and Salisbury (Oldale and Wommack, 1987; Hein and others, 2013).

The Quaternary geology of this region has been the subject of several geologic investigations (table 1). The complex surficial geology is attributed to the occupation and retreat of glacial ice sheets during the Pleistocene and subsequent sea-level change during the Holocene (Larson, 1982; Stone and Borns, 1986; Oldale and others, 1993). Most of the glacial sediments overlying bedrock and coastal plain material were deposited by the Wisconsinan Laurentide ice sheet (Oldale and Bick, 1987; Oldale and Wommack, 1987), which reached its maximum extent in eastern Massachusetts at present-day Martha's Vineyard and Nantucket about 20,000 to 24,000 years before present (BP; Uchupi and others, 1996; Oldale, 2001; Boothroyd and Sirkin, 2002). Sea-level rise was concurrent with ice-front retreat, which resulted in widespread deposition of glaciomarine sediments (Stone and Peper, 1982; Oldale and Bick, 1987; Oldale, 1988). After the glaciers retreated north of Boston, Mass., about 14,500 years BP, relative sea-level change became the dominant factor driving coastal evolution (Oldale and others, 1993). Between about 14,000 and 12,000 years BP, relative sea level fell rapidly as the region rebounded from ice removal, subaerially exposing and deeply incising the inner continental shelf with meltwater drainage systems (Oldale and Bick, 1987; Oldale and Wommack, 1987; Oldale and others, 1993). Eustatic sea-level rise outpaced waning isostatic rebound about 12,000 years BP, causing the onset of the Holocene marine transgression that continues today (fig. 2; Oldale and others, 1993). Valleys incised on the inner shelf during the regression were partially filled by fluvial and estuarine 
deposits as sea level rose and oceanographic processes eroded, reworked, and redistributed sediments across the inner shelf seaward of the transgressing shoreline.

Inner continental shelf sediments in water depths less than about $40 \mathrm{~m}$ south of Cape Ann have been extensively eroded and reworked during the Holocene marine transgression and by modern oceanographic processes (Knebel and Circe, 1995; Butman and others, 2006, 2008; Warner and others, 2008), resulting in coarse sea-floor textures characterized by winnowed glacial and lag deposits and outcropping pre-Quaternary age deposits. Rocky pavements consisting of boulders, cobbles, and gravel mixed with sand are extensive and interspersed with narrow channels and valleys filled with sand, gravel, and some mud (Knebel and Circe, 1995; Oldale and Bick, 1987). Erosion of glacial sediments on the inner continental shelf has provided sand and gravel for small pocket beaches, but the shoreline is largely bedrock framed.

The inner continental shelf surrounding Cape Ann consists of high-relief bedrock exposures to water depths of 20 to $30 \mathrm{~m}$, but sea-floor composition in deeper water to the north and south abruptly transitions to sand and muddy sands, respectively. Farther north of Cape Ann, sand is abundant along the shoreline and on the inner shelf. Sand and gravel deposited in the Merrimack paleodelta during sealevel lowstand (fig. 2) were reworked and distributed on the shelf during Holocene marine transgression (Oldale and others, 1983; Edwards, 1988; Barnhardt and others, 2009; Hein and others, 2013). Together, the modern Merrimack fluvial sediments and erosion and redistribution of the lowstand delta deposits on the inner continental shelf are responsible for creating the longest barrier island chain in the Gulf of Maine (FitzGerald and others, 1994).

Table 1. Previously published studies of sea-floor geology in the southern Merrimack Embayment and western Massachusetts Bay.

\begin{tabular}{|c|c|c|c|c|}
\hline Previous work & $\begin{array}{l}\text { Geologic framework and } \\
\text { stratigraphy }\end{array}$ & Sediment texture & $\begin{array}{c}\text { Physiographic zones } \\
\text { and morphology }\end{array}$ & $\begin{array}{c}\text { Sea-level } \\
\text { reconstruction }\end{array}$ \\
\hline $\begin{array}{l}\text { Merrimack } \\
\text { Embayment }\end{array}$ & $\begin{array}{l}\text { Oldale and others (1983); } \\
\text { Bothner and others (1983); } \\
\text { Oldale and Wommack } \\
\text { (1987); Edwards (1988); } \\
\text { FitzGerald and others } \\
\text { (1994); Oldale and others } \\
\text { (1994); Barnhardt and } \\
\text { others (2009); Hein and } \\
\text { others }(2012,2013)\end{array}$ & $\begin{array}{l}\text { Schlee and others } \\
\text { (1973); Folger and } \\
\text { others (1975); } \\
\text { Barnhardt and } \\
\text { others (2009); } \\
\text { FitzGerald and } \\
\text { Hein (2009); Ford } \\
\text { and Voss (2010) }\end{array}$ & $\begin{array}{l}\text { Barnhardt and others } \\
\text { (2009) }\end{array}$ & $\begin{array}{l}\text { Keene (1971); Oldale } \\
\text { and others (1983, } \\
\text { 1993); Stone and } \\
\text { others (2004); } \\
\text { Donnelley (2006); } \\
\text { Hein and others } \\
(2012)\end{array}$ \\
\hline $\begin{array}{l}\text { Massachusetts } \\
\text { Bay }\end{array}$ & $\begin{array}{l}\text { Oldale and others (1983, } \\
\text { 1994); Oldale and O’Hara } \\
\text { (1984); Oldale and Bick } \\
\text { (1987); Oldale (1988); } \\
\text { Barnhardt and others } \\
\text { (2006) }\end{array}$ & $\begin{array}{l}\text { Schlee and others } \\
\text { (1973); Knebel and } \\
\text { Circe (1995); } \\
\text { Barnhardt and } \\
\text { others (2006); Ford } \\
\text { and Voss (2010) }\end{array}$ & $\begin{array}{l}\text { Bothner and others } \\
\text { (1992); Knebel and } \\
\text { Circe (1995); Butman } \\
\text { and others (2003a-c, } \\
\text { 2004); Barnhardt and } \\
\text { others (2006) }\end{array}$ & $\begin{array}{l}\text { Kaye and Barghoorn } \\
\quad(1964)\end{array}$ \\
\hline
\end{tabular}

\section{Previous Work}

Surficial sediment distribution within the coastal zone of Massachusetts is complex and difficult to map because of frequent substrate changes in this glaciated region that occur over small spatial scales (tens of meters). A number of studies have discussed the geology, geologic evolution, sediment distribution, and sea-level history of the southern Merrimack Embayment and western Massachusetts Bay (table 1). Early descriptions of the sea-floor texture in this region were based on widely spaced geophysical tracklines and (or) samples (Schlee and others, 1973; Folger and others, 1975; Oldale and Bick, 1987; Oldale and Wommack, 1987; Knebel and Circe, 1995; Ford and Voss, 2010). Recent 
studies using higher data density and swath mapping technology (Butman and others, 2003a-c; 2004; Barnhardt and others, 2006, 2009; Hein and others, 2013) build upon earlier regional investigations conducted in Massachusetts Bay (Oldale and Bick, 1987) and the southern Merrimack Embayment (Oldale and Wommack, 1987). Barnhardt and others (2006) used a multivariate analysis approach to broadly define sea-floor texture into three main classes, which are sand and silt, cobble and boulder, and ledge. Although this classification is based on the same high-resolution geophysical data used by Barnhardt and others (2009) and Hein and others (2013) and used automated classification techniques, it has less application for resource management and habitat studies than a more supervised mapping technique because of the small number of texture classes and the difficulty in accurately classifying acoustic data with automated techniques (artifacts present in the data such as noise in the water column and nadir influence the accuracy of the classification).

The sea-floor characterizations presented in this report (sediment texture maps and physiographic zones) rely heavily on the geophysical and sample data and interpretations presented in Barnhardt and others (2009) and Hein and others (2013) and are supplemented with additional sediment samples, sea-floor photographs, lidar, and coastal aerial photographs. These combined datasets enable detailed and high-resolution interpretations (identifying features of $50 \mathrm{~m}$ and greater) of the complex sea-floor environment not possible in earlier studies that relied solely on sparse sediment samples and widely spaced geophysical data. The sea-floor characterizations presented can be used as input for mapping marine habitats, identifying marine resources, and developing a better understanding of coastal evolution and its response to sea-level rise.

\section{Methods}

\section{Overview}

This section describes how the interpretations presented in this report were generated. Detailed descriptions of software, source information, scale, and accuracy assessments for each dataset are provided in the metadata files for geospatial data layers in appendix 1.

\section{Geophysical Data}

The data sources for swath bathymetry, lidar, and backscatter are the same as those presented in Pendleton and others (2013; figs. 3 and 4; table 2). Rugosity derived by using DEM Surface Tools (Jenness Enterprises, 2015) and bathymetric gradient were calculated at the highest resolution of each survey (table 2). Shaded relief images were created from bathymetry exaggerated two times and illuminated with a light source from 315 degrees $\left(^{\circ}\right)$ at an elevation of $45^{\circ}$. 
Table 2. Data sources for the digital elevation model, backscatter mosaic, and seismic-reflection profile interpretations.

[These source data (swath bathymetry and backscatter mosaics) are available for download from the individual publications or as a composite dataset from Pendleton and others (2013). JALBTCX, Joint Airborne Lidar Bathymetry Technical Center of Expertise; NOAA, National Oceanic and Atmospheric Administration; UNH, University of New Hampshire; USACE, U.S. Army Corps of Engineers]

\begin{tabular}{|c|c|c|c|c|c|}
\hline Vessel & Date & Bathymetric/topographic & Backscatter & Seismic & Citation \\
\hline $\begin{array}{l}\text { Fredrick } G . \\
\quad \text { Creed }\end{array}$ & $\begin{array}{r}1994- \\
1998\end{array}$ & $\begin{array}{l}\text { Simrad Subsea EM1000 } \\
\text { multibeam echo } \\
\text { sounder }\end{array}$ & $\begin{array}{l}\text { Simrad Subsea } \\
\text { EM1000 multibeam } \\
\text { echo sounder }\end{array}$ & None & $\begin{array}{l}\text { Poppe and } \\
\text { others, } 2005\end{array}$ \\
\hline $\begin{array}{l}\text { Fredrick } G . \\
\quad \text { Creed }\end{array}$ & $\begin{array}{r}1994- \\
1998\end{array}$ & $\begin{array}{l}\text { Simrad Subsea EM1000 } \\
\text { multibeam echo } \\
\text { sounder }\end{array}$ & $\begin{array}{l}\text { Simrad Subsea } \\
\text { EM1000 multibeam } \\
\text { echo sounder }\end{array}$ & None & $\begin{array}{l}\text { Butman and } \\
\text { others, } 2007\end{array}$ \\
\hline $\begin{array}{l}\text { Whiting and } \\
\text { NOAA } \\
\text { launches }\end{array}$ & $\begin{array}{r}2000- \\
2001\end{array}$ & $\begin{array}{l}\text { RESON SeaBat } \\
\text { 8101MBS and Odom } \\
\text { Echotrac DF3200 MKII } \\
\text { single beam system }\end{array}$ & $\begin{array}{l}\text { Edgetech } 272-\mathrm{T} \text { and } \\
\text { Klein T-5500 }\end{array}$ & None & $\begin{array}{r}\text { Ackerman and } \\
\text { others, } 2006\end{array}$ \\
\hline Rafael & $\begin{array}{r}2003- \\
2004\end{array}$ & $\begin{array}{l}\text { SEA Submetrix } 2000 \\
\text { series interferometric } \\
\text { sonar }\end{array}$ & $\begin{array}{l}\text { Edgetech DF1000 dual } \\
\text { frequency sidescan } \\
\text { sonar }\end{array}$ & $\begin{array}{l}\text { Knudsen } 320 b \\
\text { chirp system }\end{array}$ & $\begin{array}{r}\text { Barnhardt and } \\
\text { others, } 2006\end{array}$ \\
\hline $\begin{array}{l}\text { Ocean } \\
\text { Explorer and } \\
\text { Connecticut }\end{array}$ & $\begin{array}{l}2004- \\
2005\end{array}$ & $\begin{array}{l}\text { RESON SeaBat } \\
\text { 8101MBS, and an SEA } \\
\text { SWATHplus } \\
\text { interferometric sonar } \\
\text { system }\end{array}$ & $\begin{array}{l}\text { RESON SeaBat } \\
\text { 8101MBS, and Klein } \\
3000 \text { dual-frequency } \\
\text { sidescan sonar }\end{array}$ & $\begin{array}{l}\text { EdgeTech Geo-Star } \\
\text { FSSB subbottom } \\
\text { profiling system } \\
\text { and an SB-0512i } \\
\text { towfish }\end{array}$ & $\begin{array}{l}\text { Barnhardt and } \\
\text { others, } 2009\end{array}$ \\
\hline $\begin{array}{l}\text { Atlantic } \\
\text { Surveyor }\end{array}$ & 2005 & RESON SeaBat 8101 & RESON SeaBat $8101^{*}$ & None & $\begin{array}{l}\text { NOAA and } \\
\text { UNH, } 2005\end{array}$ \\
\hline $\begin{array}{l}\text { Thomas } \\
\text { Jefferson }\end{array}$ & 2006 & $\begin{array}{l}\text { EM1002 MBS and Odom } \\
\text { Echotrac DF3200 MKII } \\
\text { single beam system }\end{array}$ & EM1002 MBS* & None & NOAA, 2006 \\
\hline $\begin{array}{l}\text { Megan } T . \\
\text { Miller, } \\
\text { Rafael, and } \\
\text { NOAA } \\
\text { launches }\end{array}$ & $\begin{array}{l}2006- \\
2007\end{array}$ & $\begin{array}{l}\text { RESON SeaBat } 3101 \text { or } \\
8125 \mathrm{MBS} \text {, and an SEA } \\
\text { SWATHplus } \\
\text { interferometric sonar } \\
\text { system }\end{array}$ & $\begin{array}{l}\text { RESON SeaBat } 3101 \text { or } \\
8125, \text { Klein } 3000 \\
\text { dual-frequency } \\
\text { sidescan sonar, or an } \\
\text { SEA SWATHplus } \\
\text { interferometric sonar } \\
\text { system }\end{array}$ & $\begin{array}{l}\text { EdgeTech Geo-Star } \\
\text { FSSB subbottom } \\
\text { profiling system } \\
\text { and an SB-0512i } \\
\text { towfish }\end{array}$ & $\begin{array}{l}\text { Barnhardt and } \\
\text { others, } 2010\end{array}$ \\
\hline $\begin{array}{l}\text { Megan } T \text {. } \\
\quad \text { Miller and } \\
\text { Rafael }\end{array}$ & $\begin{array}{r}2006- \\
2008\end{array}$ & $\begin{array}{l}\text { SEA SWATHplus } \\
\text { interferometric sonar } \\
\text { system }\end{array}$ & $\begin{array}{l}\text { Klein } 3000 \text { dual- } \\
\text { frequency sidescan } \\
\text { sonar, or an SEA } \\
\text { SWATHplus } \\
\text { interferometric sonar } \\
\text { system }\end{array}$ & $\begin{array}{l}\text { EdgeTech Geo-Star } \\
\text { FSSB subbottom } \\
\text { profiling system } \\
\text { and an SB-0512i } \\
\text { towfish }\end{array}$ & $\begin{array}{l}\text { Andrews and } \\
\text { others, } 2010\end{array}$ \\
\hline $\begin{array}{l}\text { JALBTCX } \\
\text { lidar plane }\end{array}$ & 2007 & SHOALS-1000T & None & None & $\begin{array}{l}\text { JALBTCX and } \\
\text { USACE, } \\
2008\end{array}$ \\
\hline
\end{tabular}

*These data were not used in the composite backscatter image. 


\section{Previous Interpretations}

Physiographic zone and seismic cross-sectional interpretations for nearshore areas between Nahant and Gloucester and Cape Ann and Salisbury are presented in Barnhardt and others (2006, 2009). Oldale and Bick (1987), Oldale and Wommack (1987), and Oldale and others (1994) presented geologic interpretations for parts of Massachusetts Bay and the inner continental shelf offshore of Cape Ann to New Hampshire. Butman and others (2006a-c; 2007) produced sea-floor topography maps and feature descriptions in western Massachusetts Bay. Hein and others (2013) produced an onshore/offshore geologic map of Newburyport and Ipswich, Mass., extending to about $90 \mathrm{~m}$ water depth. Seismic units from previously published geologic and stratigraphic interpretations were combined, providing an input map layer (surficial geologic and stratigraphic interpretations) for this study (fig. 5). Not all of the previously published geologic and stratigraphic maps were created at the same resolution, nor did they use the same naming convention for the stratigraphic units mapped. Figure 6 summarizes how the units used in previous studies were combined in this study into generalized geologic units in order to produce a map layer to inform sediment texture and physiographic zone interpretations.

\section{Sediment Samples and Sediment Texture Classification Schemes}

Sediment sample databases of Ford and Voss (2010) and McMullen and others (2011) were supplemented with National Oceanic and Atmospheric Administration chart sampling data and more than 1,700 bottom photographs and descriptions (fig. 7; Gutierrez and others, 2000; Barnhardt and others 2006, 2009; Emily Huntley, CZM, unpub. data, 2012). This study uses the Barnhardt and others (1998) sediment texture classification scheme (fig. 8). The Barnhardt and others (1998) system is based on four basic, easily recognized sediment units (as measured in grain size, based on Wentworth, 1922): rock (R; grain size greater than 64 millimeters [mm]), gravel (G; grain size greater than 2 to $64 \mathrm{~mm}$ ), sand ( $\mathrm{S}$; grain size of $0.062 \mathrm{~mm}$ to $2 \mathrm{~mm}$ ), and mud (M; grain size less than $0.062 \mathrm{~mm}$ ). Because the sea floor is often not a uniform mixture of these units, the classification is further divided into 12 composite units, which are two-part combinations of the 4 basic units (fig. 8). This classification is defined such that the primary texture, representing more than 50 percent of an area's texture, is given an uppercase letter, and the secondary texture, representing less than 50 percent of an area's texture, is given a lowercase letter. If one of the basic sediment units represents more than 90 percent of the texture, only its uppercase letter is used. The units defined under the Barnhardt and others (1998) classification within this study area include $\mathrm{R}$, gravelly rock $(\mathrm{Rg})$, sandy rock $(\mathrm{Rs})$, and muddy rock $(\mathrm{Rm})$; $\mathrm{G}$, rocky gravel (Gr), sandy gravel (Gs), and muddy gravel (Gm); S, gravelly sand (Sg), muddy sand (Sm), and rocky sand (Sr); and M, rocky mud (Mr), gravelly mud (Mg), and sandy mud (Ms).

\section{Sediment Texture Mapping}

The texture and spatial distribution of sea-floor sediment were mapped qualitatively in ArcGIS by using acoustic-backscatter intensity, bathymetry, lidar, geologic interpretations, aerial photography, bottom photographs, and sediment samples. The mapping was done by using the highest data resolution available, typically $2 \mathrm{~m}$ in water depths less than $30 \mathrm{~m}$, and $10 \mathrm{~m}$ for water depths greater than $30 \mathrm{~m}$. First, sediment texture polygons were outlined by using backscatter intensity data to define changes in the sea floor based on acoustic return (figs. 3 and $9 A$ ). Areas of high backscatter intensity (light tones) have strong acoustic reflections, suggest boulders and gravels, and generally are characterized by coarse sea-floor sediments. Low-backscatter-intensity areas (dark tones) have weak acoustic reflections and generally are characterized by fine-grained material such as muds and fine sands. 
The polygons were then refined and edited by using gradient, rugosity, and hillshaded relief images derived from interferometric and multibeam swath bathymetry and from lidar at the highest resolution available (figs. 4 and $9 B-E$ ). Areas of rough topography and high rugosity typically are associated with rocky areas, whereas smooth, low-rugosity regions tend to be blanketed by fine-grained sediment. These bathymetric derivatives helped to refine polygon boundaries where changes from areas of primarily rock to areas of primarily gravel may not have been apparent in backscatter data but could easily be identified in hillshaded relief, rugosity and slope data (figs. 9 and 10).

The third data input was the stratigraphic and geologic interpretation of seismic-reflection profiles, which further constrained the extent and general shape of sea-floor sediment distributions and rocky outcrops and also provided insight concerning the likely sediment texture based on the preQuaternary, glacial, or postglacial origin (figs. 5 and 10; Barnhardt and others, 2006; Oldale and Bick, 1987; Oldale and Wommack, 1987; Oldale and others, 1994; Hein and others, 2013).

Finally, bottom photographs and sediment samples (fig. 7) were used to define sediment texture for each polygon that was drawn by using geophysical data (fig. 10). Percentages of gravel, sand, silt, and clay and phi size for each sediment texture polygon were calculated by using grain-size statistics of laboratory-analyzed sediment samples within the defined polygon. Texture data based on laboratory grain-size analysis were preferred over visual descriptions when defining sediment texture throughout the study area. Of the more than 6,000 samples in total within the study area, 1,215 were analyzed in the laboratory for grain size (fig. 7). Sediment texture statistics for each polygon can be found within the geospatial data file (Nahant_NH_sedcover.shp) for sediment texture in appendix 1. The number of sediment samples in a polygon ranged from 0 to 166 . For multiple samples within a polygon, the dominant sediment texture (as defined by Barnhardt and others [1998] or average phi size, when available) was used to classify sediment type. Average phi size and average particle content by weight data were not typically representative and frequently not available in rock and gravel areas because the grab sampler could not sample the range of sediment sizes on the sea floor because of large particles. In these areas, bottom photographs were used in the absence of sediment samples to qualitatively define sediment texture. The average texture statistics are most representative in polygons with several samples and textures in the sand and smaller sediment classes. Polygons that lacked sample information (23 percent of the interpreted area) were defined texturally through extrapolation from adjacent or proximal polygons of similar acoustic character that did contain sediment samples ( 77 percent of interpreted area).

\section{Physiographic Zones}

The sea floor within the study area was divided into physiographic zones by following the methods used in other parts of the Gulf of Maine (Kelley and Belknap, 1991; Kelley and others, 1996; Barnhardt and others, 2006, 2009; and Pendleton and others, 2013). The distribution of sea-floor physiographic zones was analyzed qualitatively in ArcGIS by using the same input sources and digitization techniques used to determine sediment texture and distribution (figs. 9 and 10). Physiographic zones identified within the study area include rocky zones, outer basins, nearshore basins, ebb-tidal deltas, hard-bottom plains, nearshore ramps, and shelf valleys. 


\section{Results}

\section{Sediment Texture and Distribution}

Sediment texture and distribution were mapped for more than 1,043 square kilometers $\left(\mathrm{km}^{2}\right.$; fig. 11) by using the Barnhardt and others (1998) classification (fig. 8). The data were interpreted at a scale ranging from 1:8,000 to 1:25,000, depending on the resolution of the source geophysical grids and the sample data density.

Sediments within the study area represent nearly all particle sizes. Sediment texture ranges from muddy sediments offshore and in semiprotected settings along the coast to pebbles, cobbles, and boulders where drumlins, till, lag deposits, and bedrock are exposed at the sea floor (figs. 11, 12, and 13). Both coarse- and fine-grained sediment exist in all water depths; however, in general, finegrained sediments are in the deeper water (greater than about $50 \mathrm{~m}$ ), and rocky textures are more prevalent along the nearshore margins of the bedrock-framed coastline and in western Massachusetts Bay (figs. 11 and 13). Rocky textures are least concentrated north of Cape Ann in the southern Merrimack Embayment (figs. 11 and 12). A mean sorting value of 1.6 suggests that the sediment is poorly sorted in the entire region, which is consistent with a reworked glacial environment. Overall, the samples in the texture database for the study area are 62 percent sand, 33 percent mud, and 5 percent gravel by weight.

Sand (greater than $0.062 \mathrm{~mm}$ to $2 \mathrm{~mm}$ ) is the dominant bottom sediment type within the study area and is interpreted to cover 53 percent of the sea floor by area (fig. 11). Sand is most extensive north of Cape Ann. Muddy sediments, which include silt- and clay-size particles less than $0.062 \mathrm{~mm}$ in diameter, cover about 17.5 percent of the sea floor by area (fig. 14). Samples with the highest mud percentages were primarily collected in water depth greater than $60 \mathrm{~m}$. Sediments from around Cape Ann and to the south are highly variable in terms of mud content, ranging from 0 percent to 92 percent mud with an average of 26 percent in water depths less than $60 \mathrm{~m}$. However, north of Cape Ann mud content is low, ranging from 0 to 40 percent with an average of less than 4 percent in water depths less than $60 \mathrm{~m}$ (fig. 12). Gravel or particles greater than $2 \mathrm{~mm}$ but less than $64 \mathrm{~mm}$ (-1 to -6 phi) in diameter are interpreted to be the primary sediment cover for 7.5 percent of the sea floor. Many photographs document the occurrence of gravel and cobble in rocky areas where sediment samplers were unable to recover large-diameter particles, suggesting that gravel and rock are underrepresented in sediment sample data in this area. Primarily rocky areas are interpreted to cover about 22 percent of the sea floor by area and are most prevalent adjacent to rocky headlands along the coast or associated with reworked glacial deposits in western Massachusetts Bay (figs. 11 and 13).

\section{Physiographic Zones}

The areal distribution of physiographic zones in the offshore portion of the study area $\left(517 \mathrm{~km}^{2}\right)$ was interpreted at a scale ranging from 1:8,000 to 1:25,000, depending on the resolution of the source geophysical grids. Physiographic zone interpretations of Barnhardt and others $(2006,2009)$ and Pendleton and others (2013) are shown adjacent to the physiographic zones identified in this study (fig. 15).

Rocky zones are rugged areas of high bathymetric relief, ranging from nearly vertical rock cliffs to relatively flat, gravel-covered plains with boulders several meters in diameter. Although coarsegrained sediments locally occur in all physiographic zones, they dominate the sea floor in rocky zones. Rocky zones are extensive in the nearshore from Nahant to Gloucester ( 37 percent of the sea floor by area; Barnhardt and others, 2006), adjacent to Cape Ann, and throughout western Massachusetts Bay 
(33 percent of the sea floor by area; fig. 15), but are relatively sparse north of Cape Ann (5 percent of the sea floor by area; Barnhardt and others, 2009).

Outer basins are associated with the seaward extent of the inner continental shelf. They are generally found in water depths greater than $40 \mathrm{~m}$ and are typically of a finer texture than shallower water sediments but may contain occasional rock outcrops. Outer basins are the third most common physiographic zone in area of western Massachusetts Bay in the study, making up 20 percent of the sea floor. Barnhardt and others (2006) found no outer basins in the nearshore area from Nahant to Gloucester (likely due to the shallow water depths within the survey area), and roughly 27 percent of the sea floor north of Cape Ann is classified as outer basin (Barnhardt and others, 2009). Sediment samples within the outer basins range from sand to muddy sediments. Outer basins are locally interrupted by outcrops of pre-Quaternary age coastal plain sediments, Paleozoic bedrock, and coarse-grained glacial deposits classified as rocky zones or hard-bottom plains (till and drumlins; Hein and others, 2013; Oldale and Wommack, 1987).

Nearshore basins are areas of shallow, low-relief sea floor adjacent to the mainland, which are separated from offshore areas by islands or shoals. Nearshore basins make up less than four percent of the sea floor by area (fig. 15; Barnhardt and others 2006, 2009) and are found primarily north and east of Marblehead, Mass., adjacent to rocky headlands. Surficial sediment samples within nearshore basins indicate that these zones are filled with rock and gravel to muddy sediments and their composition is related to that of adjacent features, such that fine-grained nearshore basins (muddy with locally coarse sediment) occur near fine-grained areas like Gloucester Harbor, Manchester Bay, and Salem Sound (Barnhardt and others, 2006), whereas coarse-grained nearshore basins (sandy to gravelly sediments) are within Boston's outer harbor (Pendleton and others, 2013) and western Massachusetts Bay.

Ebb-tidal deltas and bay mouth shoals are only present within areas interpreted by Barnhardt and others $(2006,2009)$ and are not discussed here as part of the interpretation of western Massachusetts Bay and the southern Merrimack embayment. Combined ebb-tidal deltas and bay mouth shoals comprise just more than 1 percent of the sea floor within the study area (Barnhardt and others, 2006, 2009).

Hard-bottom plains tend to have low bathymetric relief, with a coarse sediment texture consisting of primarily gravel, sand, and rock. Hard-bottom plains account for about 4 percent of the sea floor within the study area and are concentrated in western Massachusetts Bay in intermediate water depths $(15-30 \mathrm{~m})$ and are likely associated with lag deposits (fig. 15). There are no hard-bottom plains identified north of Cape Ann (Barnhardt and others, 2009).

Nearshore ramps are areas of gently sloping sea floor with generally shore-parallel bathymetric contours. These zones are primarily covered with sand-rich sediment, although small exposures of cobbles and boulders locally crop out on the sea floor. Nearshore ramps are the primary physiographic zone north of Cape Ann (64 percent of the sea floor by area; Barnhardt and others, 2009) and from Nahant to Gloucester (40 percent of the sea floor by area; Barnhardt and others, 2006). In the physiographic zones presented in this report, however, nearshore ramps account for less than 20 percent of the sea floor by area, which is likely due to the significant offshore area included in the report (fig. 15).

Shelf valleys are elongate depressions that extend offshore, often perpendicular to the trend of the coastline, and slope gently seaward. Shelf valleys represent about 15 percent of the study area but are somewhat less prevalent in the more nearshore study areas presented by Barnhardt and others (2006, 2009; fig. 15). These zones are interpreted to have formed by fluvial erosion during periods of lowerthan-present sea level and are most commonly dominated by sandy textures. 


\section{Discussion}

Complete coverage of the sea floor with geophysical data at a spatial resolution of 2 to $10 \mathrm{~m}$ provides a previously unavailable means of interpreting the sea-floor. The following section outlines our confidence in the interpretations and some of their limitations, and it indicates how these data are combined to create a high-resolution, in-depth view of the sea-floor environment in the region.

\section{Confidence and Limitation in Interpretations}

Because all data input sources were not available in all parts of the study area, qualitatively defined polygons of sediment texture were assigned a data interpretation confidence value between 1 (highest) and 4 (lowest) based on the quality and number of data sources available (fig. 16). Sediment texture regions that were defined on the basis of the highest resolution bathymetry $(5 \mathrm{~m})$ and backscatter $(1 \mathrm{~m})$, bottom photographs, sediment samples, and seismic interpretations (Barnhardt and others 2006, 2009) were given the highest data interpretation confidence value of 1 . Areas with a confidence value of 1 (very high confidence) include areas in the Nahant to Gloucester and Cape Ann to Salisbury studies published by Barnhardt and others (2006, 2009). A confidence value of 2 (high confidence) was given to areas with multibeam bathymetry and backscatter data of 10-m resolution and sediment samples and bottom photographs (Butman and others, 2007; Gutierrez and others, 2000), but only sparse-density seismic interpretations with regional-scale geologic maps were available (Odale and Bick, 1987; Oldale and Wommack, 1987; Oldale and others, 1994). The high-confidence (2) area is primarily offshore, east from Cape Ann to the southern extent of the study area, generally in water depths greater than 10-20 m. Moderate-confidence values (3) were assigned to nearshore areas (typically shallower than $5 \mathrm{~m}$ ), where only lidar data of 2.5-m resolution, aerial photography, and sediment samples were available. Lowconfidence values (4) are generally assigned to small areas of sea floor where lidar data were not collected or areas too shallow and rocky to navigate by boat. Interpretations in these relatively small (on average less than $1 \mathrm{~km}^{2}$ ) low-confidence areas were made from aerial photographs, sediment samples, and extrapolation from adjacent areas of higher confidence.

The qualitative interpretations are limited because the resolutions of the source geophysical data and the spacing of sediment samples do not capture all variations in sea-floor texture. The data were interpreted at scales between 1:8,000 and 1:25,000, but the recommended scale for application of the results is greater than 1:25,000. In general, features below 5,000 square meters or less than 50 m wide were not digitized because of positional uncertainty, lack of sample information, and the often ephemeral nature of small-scale sea-floor features (for example, bedforms). Not all digitized sea-floor features contained sample or photographic information; therefore, sea-floor texture is sometimes determined on the basis of the nearest similar feature that contains a sample. Conversely, sometimes a digitized feature contained multiple samples that were not all of the same texture. In these cases, the texture within the polygon was defined by the dominant sediment texture (based on Barnhardt and others, 1998) or mean phi size, when available. Ground truth data in rocky areas often are limited to bottom photographs because the sampling devices are not physically designed to collect cobbles or boulders. Sediment texture interpretation based on bottom photograph classification is subjective, such that the dominant sediment type within the view frame is an estimate determined by the interpreter and may differ among interpreters. Furthermore, particle size cannot be accurately determined in bottom photographs; the division between gravel and rock $(64 \mathrm{~mm})$ as perceived in bottom photographs is an approximation. Bottom photograph transects often reveal changes in the sea floor over distances of less than $100 \mathrm{~m}$, and these changes are often not captured in acoustic data. Sea-floor texture in reworked glacial environments can change over short distances (meters), and many small-scale changes will not 
be detectable or mappable at a scale of 1:25,000. The boundaries of polygons are often inferred on the basis of sediment samples, and even boundaries that are traced on the basis of backscatter intensity or rugosity changes in geophysical data are subject to migration and positional uncertainty. Polygon boundaries should be considered an approximation of the location of a change in texture.

\section{Sediment Classification}

The Barnhardt and others (1998) classification was chosen as the most representative classification scheme for defining sea-floor texture for this study area because of the complex nature and heterogeneity of sea-floor material and the scale at which these data are mapped. This system works well for inner shelf environments where one sediment unit is generally inadequate for representing seafloor texture, such as the New England coast, where reworked tills and rocky pavements are common.

\section{Linking the Interpretations}

Surficial geologic units of Oldale and Bick (1987), Oldale and Wommack (1987), Oldale and others (1994), Hein and others (2013), and Barnhardt and others (2006, 2009) can be linked to the areal distribution of surficial sediment distribution and physiographic zones presented here (figs. 5, 11, and 15). Bedrock outcrops are most extensive along the nearshore of western Massachusetts Bay and Cape Ann and account for roughly 9 percent of the interpreted sea floor by area (fig. 5). Bedrock outcrops correspond to rocky zones and hard-bottom plains, where the most common sediment textures are R, Rs, Rg, and less often Gr.

Wisconsinan- and earlier Pleistocene-age glacial sediments crop out throughout western Massachusetts Bay and are sparse north of Cape Ann. Pleistocene glacial units interpreted by Oldale and Bick (1987), Oldale and Wommack (1987), Oldale and others (1994), and Hein and others (2013), comprise roughly 30 percent of the sea floor within interpreted areas and are most often associated with dominant surficial sediment textures R, G, and S. Glacial deposits include all sediment types, but they are largely winnowed on the inner shelf in western Massachusetts Bay and include gravel and rock pavements, lag deposits, and topographic highs interpreted to be drowned drumlins (Oldale and others, 1994). Glacial sediments cropping out on the inner shelf north of Cape Ann are identified by Hein and others (2013) as drumlins and are likely Illinoian in age (Newman and others, 1990). Glacial deposits in western Massachusetts Bay are more extensive than in the southern Merrimack Embayment and are described by Oldale and Bick (1987) as glacial-marine deposits that can include subaqueous stratified ice-contact material, outwash, till, and drift. Oldale and others (1994) identified a submerged drumlin field within the study area thought to be cored by till of Illinoian age (fig. 5).

Lowstand deposits including late Pleistocene to early Holocene age fluvial, estuarine, and deltaic sediments (Oldale and others, 1983; Oldale and Wommack, 1987; Hein and others, 2013) cover approximately 10 percent of the sea floor in the interpreted area (fig. 5). A lowstand delta in the southern Merrimack embayment was first described by Oldale and others (1983). The majority of the paleodelta surface, foresets, and fluvial and estuarine network has been truncated, reworked, and subsequently buried (fig. 17; Oldale and others, 1983). The abundance of sand on the inner shelf and within the barrier island system of the southern Merrimack Embayment is attributed to the erosion of fluvial and deltaic sediments from the drowned Merrimack River Delta and the subsequent redeposition of these sediments through transgressive marine processes (FitzGerald and others, 1994). Samples from sites where the delta sediments are thought to be exposed at the sea floor contain on average 77 percent sand, 8 percent gravel, and 15 percent mud. The seaward extent of the paleodelta marks the transition from outer basin to nearshore ramp in the physiographic zone interpretation of Barnhardt and others (2009). 
South of Cape Ann, fluvial and estuarine deposits are concentrated in water depths less than $50 \mathrm{~m}$, or roughly the extent of the shoreline at the sea-level lowstand (Oldale and Bick, 1987). The geologic interpretation of Oldale and Bick (1987) did not extend onshore beyond the 30-m contour, but it is likely that the fluvial and estuarine deposits interpreted at the landward extent of the study continued onshore between bedrock outcrops interpreted by Barnhardt and others (2006; fig. 18) and were eroded and reworked during the Holocene marine transgression. The average sand content within interpreted fluvial and estuarine deposits in western Massachusetts Bay is 91 percent sand, with 4 and 5 percent gravel and mud, respectively. Fluvial and estuarine deposits are most often associated with shelf valleys and nearshore ramp physiographic zones in western Massachusetts Bay.

Holocene-age sandy units or modern beach and bar deposits as described by Oldale and Bick (1987) and Oldale and Wommack (1987) are abundant in the southern Merrimack Embayment. A Holocene sand sheet covers nearly 65 percent of the inner shelf north of Cape Ann and is on average 90 percent sand with 7 and 3 percent gravel and mud, respectively. South of Cape Ann, Holocene sand units are small and sparse, only about 6 percent of the area interpreted by Oldale and Bick (1987). Holocene sand accumulations in western Massachusetts Bay were derived from the erosion of generally poorly sorted glacial deposits, which yielded much less sand to the inner continental shelf and shoreline during the marine transgression when compared to the Merrimack paleodelta north of Cape Ann. Holocene sands are most commonly associated with nearshore ramp physiographic zones throughout the study area.

Holocene muds or Holocene marine deposits are primarily seaward of the 50-m isobath within the study area. North of Jeffreys Ledge, areas interpreted as Holocene muds are composed of 60 percent mud and 30 percent sand. From Jeffreys Ledge to the south, sand and mud contents are slightly less (58 and 36 percent, respectively) because of slightly higher average gravel content ( 6 percent). Holocene muds are most closely correlated with the location of outer-basin physiographic zones.

\section{Coastal Evolution and Modern Processes on the Inner Continental Shelf}

The comparison between the spatial distributions of outcropping geologic units and sea-floor sediment textures provides insight to sea-floor composition and the physical processes that have affected regional sediment texture patterns (figs. 5, 11, and 15). Massachusetts Bay is largely a reworked Pleistocene surface (fig. 5). The coarsest textures (Rg, Rs, and Gr) are most prevalent within western Massachusetts Bay, where bedrock outcrops and reworked and winnowed glacial deposits are expansive. Textures generally become fine offshore as depth increases into Stellwagen Basin; the sea floor transitions from bedrock along the coast (Barnhardt and others, 2006) to local outcrops of bedrock interspersed within winnowed glacial and fluvial deposits, and then to fine-grained marine deposits in water depths greater than $50 \mathrm{~m}$. This pattern of coarse sediment textures nearshore in western Massachusetts Bay and fining offshore is consistent with storm-driven sediment transport studies conducted by Warner and others (2008). The largest wave-driven bottom stresses in this region are associated with northeastern storms (Butman and others, 2008). Numerical simulations of sediment transport in Massachusetts Bay during these storms show that storm-generated waves and currents resuspend and transport nearshore sediment to the south into Cape Cod Bay and offshore toward Stellwagen Bank. Large-amplitude internal waves, generated by tidal flow across Stellwagen Bank in summer, also winnow and transport fine-grained sediments from the western shore of Massachusetts Bay offshore toward Stellwagen Basin (Butman and others, 2006). The marine transgression likely winnowed much of the surficial fine-grained sediment from glacial deposits on the inner shelf, and modern processes maintain an armored surface by transporting fine-grained sediments to deeper, more quiescent environments than nearshore environments (Stellwagen Basin, Cape Cod Bay, and offshore). 
North of Cape Ann in the southern Merrimack Embayment, the surficial sediments are shaped by events of the late Pleistocene and Holocene, specifically the deposition of a lowstand delta following deglaciation (Oldale and others, 1983). Subsequent reworking of the delta and fluvial units during the Holocene marine transgression liberated sand to form shoals, beaches, barriers, and estuaries. As a result, more than $200 \mathrm{~km}^{2}$ of the inner continental shelf is a broad low-relief ramp composed of sand and gravel that stands in contrast to the more complex sediment textural distribution within western Massachusetts Bay. Northeastern storms are the highest energy events north of Cape Ann and often result in significant beach erosion along the barrier island chain. Analysis of bedforms and wave data on the inner continental shelf indicates that strong northeastern storms are capable of generating bottom shear stresses that could rework the inner shelf sand sheet to water depths of $50 \mathrm{~m}$ (Hein and others, 2007). This would indicate that the modern inner continental shelf as far as $10 \mathrm{~km}$ offshore is capable of being mobilized and reworked during storms and the boundaries defining sediment texture in this study are subject to change as the sea floor continues to evolve.

\section{Summary}

The interpretations presented in this report represent a unique geologic dataset for a nearshore area of the Massachusetts sea floor between Nahant and Salisbury, including a portion of western Massachusetts Bay and the southern Merrimack Embayment. The sediment texture and physiographic zone maps document the sedimentary environments of the Massachusetts inner continental shelf at a resolution that was previously not possible because of a lack of high-resolution, regional geophysical data. Previously published geologic interpretations, high-resolution geophysical data, sediment samples, aerial photographs, lidar, and bottom photographs were used to generate these interpretations. The seafloor geology within western Massachusetts Bay is a complex and variable distribution of sediments and geomorphic features that can be primarily attributed to the advances, occupations, and retreats of Pleistocene glaciers and to the reworking of glacial sediments during sea-level change. Modern processes continue to shape the sea floor. However, in the southern Merrimack Embayment, the sea floor geology is more attributable to lowstand fluvial and subsequent marine transgressive processes that blanketed the sea floor with sand and gravel. The high-resolution geologic interpretations provided in this report are valuable input for defining marine resources and improving our understanding of coastal evolution in the region.

\section{References Cited}

Ackerman, S.D., Butman, Bradford, Barnhardt, W.A., Danforth, W.W., and Crocker, J.M., 2006, Highresolution geologic mapping of the inner continental shelf-Boston Harbor and approaches, Massachusetts: U.S. Geological Survey Open-File Report 2006-1008, 1 DVD-ROM. [Also available at http://woodshole.er.usgs.gov/pubs/of2006-1008/].

Andrews, B.D., Ackerman, S.D., Baldwin, W.E., and Barnhardt, W.A., 2010, Geophysical and sampling data from the inner continental shelf-Northern Cape Cod Bay, Massachusetts: U.S. Geological Survey Open-File Report 2010-1006, 1 DVD-ROM. [Also available at http://pubs.usgs.gov/of/2010/1006/].

Barnhardt, W.A., Ackerman, S.D., Andrews, B.D., and Baldwin, W.E., 2010, Geophysical and sampling data from the inner continental shelf-Duxbury to Hull, Massachusetts: U.S. Geological Survey Open-File Report 2009-1072, 1 DVD-ROM. [Also available at http://pubs.usgs.gov/of/2009/1072/].

Barnhardt, W.A., Andrews, B.D., Ackerman, S.D., and Baldwin, W.E., 2009, High-resolution geologic mapping of the inner continental shelf-Cape Ann to Salisbury Beach, Massachusetts: 
U.S. Geological Survey Open-File Report 2007-1373, 1 DVD-ROM. [Also available at http://pubs.usgs.gov/of/2007/1373/].

Barnhardt, W.A., Andrews, B.D., and Butman, Bradford, 2006, High-resolution geologic mapping of the inner continental shelf-Nahant to Gloucester, Massachusetts: U.S. Geological Survey Open-File Report 2005-1293, 1 DVD-ROM. [Also available at http://pubs.usgs.gov/of/2005/1293/].

Barnhardt, W.A., Kelley, J.T., Dickson, S.M., and Belknap, D.F., 1998, Mapping the gulf of Maine with side-scan sonar-A new bottom-type classification for complex seafloors: Journal of Coastal Research, v. 14, no. 2, p. 646-659.

Boothroyd, J.C., and Sirkin, Les., 2002. Quaternary geology and landscape development of Block Island and adjacent regions, in Paton, P.W., Gould, L.L., August, P.V., and Frost, A.O., eds., The ecology of Block Island: Kingston, R.I., The Rhode Island Natural History Survey, p. 13-27.

Bothner, M.H., Parmenter, C.M., Twichell, D.C., Polloni, C.F., and Knebel, H.J., 1992, A geologic map of the sea floor in western Massachusetts Bay, constructed from digital sidescan sonar images, photography, and sediment samples: U.S. Geological Survey Digital Data Series, DDS-3, 1 CDROM. [Also available at http://pubs.usgs.gov/dds/dds3/].

Bothner, W.A., Simpson, R.W., Eskenasy, Diane, Shride, A.F., Oldale, R.N., Gage, T.B., 1983, Preliminary interpretation of marine sparker reflection profiles offshore from Cape Ann, Massachusetts, to Hampton, New Hampshire: U.S. Geological Survey Open-File Report 1983-460, 29 p., 2 pls.

Butman, Bradford, Alexander, P.S., Scotti, A., Beardsley, R.C., and Anderson, S.P., 2006, Large internal waves in Massachusetts Bay transport sediments offshore: Continental Shelf Research, v. 26, no. 17-18, p. 2029-2049. [Also available at http://dx.doi.org/10.1016/j.csr.2006.07.022.]

Butman, Bradford, Hayes, Laura, Danforth, W.W. and Valentine, P.C., 2003a, Sea floor topography of quadrangle 2 in western Massachusetts Bay offshore of Boston, Massachusetts: U.S. Geological Survey Investigations Series Map I-2732-A, 1 sheet, scale 1:25,000. [Also available at http://pubs.usgs.gov/imap/i-2732a/.]

Butman, Bradford, Hayes, Laura, Danforth, W.W., and Valentine, P.C., 2003b, Shaded relief and seafloor topography of quadrangle 2 in western Massachusetts Bay offshore of Boston, Massachusetts: U.S. Geological Survey Geologic Investigations Series Map I-2732-B, scale 1:25,000. [Also available at http://pubs.usgs.gov/imap/i-2732b/.]

Butman, Bradford, Hayes, Laura, Danforth, W.W., and Valentine, P.C., 2003c, Backscatter intensity and shaded relief of quadrangle 2 in western Massachusetts Bay offshore of Boston, Massachusetts: U.S. Geological Survey Geologic Investigations Series Map I-2732-C, 1 sheet, scale 1:25,000. [Also available at $\mathrm{http}: / /$ pubs.usgs.gov/imap/i-2732c/.]

Butman, Bradford, Sherwood, C.R., and Dalyander, P.S., 2008, Northeast storms ranked by wind stress and wave-generated bottom stress observed in Massachusetts Bay, 1990-2006: Continental Shelf Research, v. 28, no. 10-11, p. 1231-1245. [Also available at http://dx.doi.org/10.1016/j.csr.2008.02.010.]

Butman, Bradford, Valentine, P.C., Danforth, W.W., Hayes, Laura, Serrett, L.A., and Middleton, T.J., 2004, Shaded relief, backscatter intensity and sea floor topography of Massachusetts Bay and the Stellwagen Bank region, offshore of Boston, Massachusetts: U.S. Geological Survey Geologic Investigation Map I-2734, 2 sheets, scale 1:125,000. [Also available at http://pubs.usgs.gov/imap/i2734/.]

Butman, Bradford, Valentine, P.C., Middleton, T.J., and Danforth, W.W., 2007, A GIS library of multibeam data for Massachusetts Bay and the Stellwagen Bank National Marine Sanctuary, offshore 
of Boston, Massachusetts: U.S. Geological Survey Data Series 99, 1 DVD-ROM. [Also available at http://pubs.usgs.gov/ds/99/.]

Cameron, Barry, and Naylor, R.S., 1976, General geology of southeastern New England, in Cameron, Barry, ed., Geology of southeastern New England-A guidebook for field trips to the Boston area and vicinity, in Cameron, Barry, ed., New England Intercollegiate Geological Conference, 68th annual meeting, Boston, Mass., 1976: Princeton, N.J., Science Press, p. 13-27.

Donnelley, J.P., 2006, A revised late Holocene sea-level record for northern Massachusetts, USA: Journal of Coastal Research, v. 22, p. 1051-1061.

Edwards, G.B., 1988, Late Quaternary geology of northeastern Massachusetts and Merrimack Embayment, western Gulf of Maine: Boston, Mass., Boston University, master's thesis, 213 p.

FitzGerald, D.M., and Hein, C.J., 2009, Documenting sand and gravel resources on the inner continental shelf-Merrimack Embayment, New England: Report for U.S. Minerals Management Service, 100 p., http://www.boem.gov/Non-Energy-Minerals/MA_2009_Fitzgerald.aspx.

FitzGerald, D.M., van Heteren, Sytze, and Rosen, P.S., 1994, New England barriers, in Davis, R.A., Jr., ed., Geology of Holocene barrier island systems: Berlin, Springer-Verlag, p. 305-394.

Folger, D.W., O'Hara, C.J., and Robb, J.M., 1975, Maps showing bottom sediments on the continental shelf off the northeastern United States - Cape Ann, Massachusetts to Casco Bay, Maine:

U.S. Geological Survey Miscellaneous Investigations Series Map I-839, 2 sheets.

Ford, K.H. and Voss, S.E., 2010, Seafloor sediment composition in Massachusetts determined using point data: Massachusetts Division of Marine Fisheries Technical Report TR-45, 21 p., accessed June 4, 2013, at http://www.mass.gov/eea/docs/dfg/dmf/publications/tr-45.pdf.

Gutierrez, B.T., Butman, Bradford, and Blackwood, D.S., 2000, Photographs of the sea floor in western Massachusetts Bay, offshore of Boston, Massachusetts: U.S. Geological Survey Open-File Report 00427 CD-ROM. [Also available at http://pubs.usgs.gov/of/2000/of00-

427/mbaygis/mb_pages/toc_isbl.htm.]

Hein, C.J., FitzGerald, D.M., and Barnhardt, W.A., 2007, Holocene reworking of a sand sheet in the Merrimack Embayment, western Gulf of Maine: Journal of Coastal Research, International Coastal Symposium 2007 proceedings, p. 863-867.

Hein, C.J., FitzGerald, D.M., Barnhardt, W.A., and Stone, B.D., 2013, Onshore-offshore surficial geologic map of the Newburyport East and northern half of the Ipswich quadrangles: Massachusetts: Massachusetts Geological Survey Geologic Map GM-13-01, scale 1:24,000.

Hein, C.J., FitzGerald, D.M., Carruthers, E.A., Stone, B.D., Barnhardt, W.A., and Gontz, A.M., 2012, Refining the model of barrier island formation along a paraglacial coast in the Gulf of Maine: Marine Geology, v. 307-310, p. 40-57.

Jenness Enterprises, 2015, Raster- and TIN-based analytic tools-DEM Surface Tools v. 2.1.375: Jenness Enterprises ArcGIS Tools Web page, accessed July 15, 2015, at http://www.jennessent.com/arcgis/arcgis_extensions.htm.

Joint Airborne Lidar Bathymetry Technical Center of Expertise and U.S. Army Corps of Engineers, 2008, Massachusetts lidar grid data in coastal areas: San Diego, Calif., Fugro Pelagos, Inc. digital data.

Kaye, C.A., and Barghoorn, E.S., 1964, Late Quaternary sea-level change and crustal rise at Boston, Massachusetts, with a note on the autocompaction of peat: Geological Society of America Bulletin, v. 75, p. $63-80$.

Keene, H.W., 1971, Post glacial submergence and salt marsh evolution in New Hampshire: Maritime Sediments, v. 7, p. 64-68. 
Kelley, J.T., Barnhardt, W.A., Belknap, D.F., Dickson, S.M., and Kelley, A.R., 1996, The seafloor revealed-The geology of the northwestern Gulf of Maine inner continental shelf: Maine Geological Survey Open-File Report 96-6, 55 p. [Also available at http://www.maine.gov/doc/nrimc/mgs/explore/marine/seafloor/contents.htm.]

Kelley, J.T., and Belknap, D.F., 1991, Physiography, surficial sediments and Quaternary stratigraphy of the inner continental shelf and nearshore region of the Gulf of Maine: Continental Shelf Research, v. 11, p. 1265-1283.

Knebel, H.J., and Circe, R.C., 1995, Seafloor environments within the Boston Harbor-Massachusetts Bay sedimentary system-A regional synthesis: Journal of Coastal Research, v. 11, no. 1, p. 230-251. Larson, G.J., 1982, Nonsynchronous retreat of ice lobes from southeastern Massachusetts, in Larson, G.J., and Stone, B.D., eds., Late Wisconsinan glaciation of New England: Dubuque, Iowa, Kendall/Hunt, p. 101-113.

Massachusetts Office of Coastal Zone Management, 2015, Sediment mapping-Massachusetts Office of Coastal Zone Mapping's seafloor and habitat mapping program: Massachusetts Office of Coastal Zone Management Web page, accessed July 15, 2015, at http://www.mass.gov/eea/agencies/czm/program-areas/seafloor-and-habitat-mapping/sedimentmapping/.

McMullen, K.Y., Paskevich, V.F., and Poppe, L.J., 2011, GIS data catalog (version 2.2), in Poppe, L.J., Williams, S.J., and Paskevich, V.F., eds., 2005, USGS east-coast sediment analysis - Procedures, database, and GIS data: U.S. Geological Survey Open-File Report 2005-1001, http://woodshole.er.usgs.gov/openfile/of2005-1001/htmldocs/datacatalog.htm.

National Oceanic and Atmospheric Administration and University of New Hampshire, 2005, Gulf of Maine mapping initiative, priority 1 area survey report: Newport, Rhode Island, Science Applications International Corporation Document 05-TR-017, 22 p., 7 appendixes. [Also available at http://surveys.ngdc.noaa.gov/mgg/MB/ocean/atlantic_surveyor/GOMMI05/multibeam/data/version1/ metadata/GOMMI05.pdf.]

National Oceanic and Atmospheric Administration, 2006, Descriptive report-Hydrographic survey H11421: National Oceanic and Atmospheric Administration S-A902-TJ-05, 12 p. [Also available at http://surveys.ngdc.noaa.gov/mgg/NOS/coast/H10001-H12000/H11421/DR/H11421.pdf.]

Newman, W.A., Berg, R.C., Rosen, P.S. and Glass, H.D., 1990, Pleistocene stratigraphy of the Boston Harbor drumlins, Massachusetts: Quaternary Research, v. 32, no. 2, p. 148-159.

Oldale, R.N., 1988, A late Wisconsinan marine incursion into Cape Cod Bay, Massachusetts: Quaternary Research, v. 30, p. 237-250.

Oldale, R.N., 2001, Cape Cod, Martha's Vineyard and Nantucket—The geologic story revised and updated: East Orleans, Mass., Parnassus Imprints, 208 p.

Oldale, R.N, and Bick, Jennifer, 1987, Maps and seismic profiles showing geology of the inner continental shelf, Massachusetts Bay, Massachusetts: U.S. Geological Survey Miscellaneous Field Studies Map MF-1923, 4 sheets.

Oldale, R.N., Colman, S.M., and Jones, G.A., 1993, Radiocarbon ages from two submerged strandline features in the western Gulf of Maine and a sea-level curve for the northeastern Massachusetts coastal region: Quaternary Research, v. 40, p. 38-45.

Oldale, R.N., Knebel, H.J., and Bothner, M.H., 1994, Submerged and eroded drumlins off northeastern Massachusetts: Geomorphology, v. 9, p. 301-309.

Oldale, R.N., and O'Hara, C.J., 1984, Glaciotectonic origin of the Massachusetts coastal end moraines and a fluctuating late Wisconsinan ice margin: Geological Society of America Bulletin, v. 95, p. 61-74. 
Oldale, R.N., and Wommack, L.E., 1987, Maps and seismic profiles showing geology of the inner continental shelf, Cape Ann, Massachusetts to New Hampshire: U.S. Geological Survey Miscellaneous Field Studies Map MF-1892, 4 sheets.

Oldale, R.N., Wommack, L.E., and Whitney, A.B., 1983, Evidence for a postglacial low relative sealevel stand in the drowned delta of the Merrimack River, western Gulf of Maine: Quaternary Research, v. 19, p. 325-336.

Pendleton, E.A., Baldwin, W.E., Barnhardt, W.A., Ackerman, S.D., Foster, D.S., Andrews, B.D., and Schwab, W.C., 2013, Shallow geology, seafloor texture, and physiographic zones of the inner continental shelf from Nahant to northern Cape Cod Bay, Massachusetts: U.S. Geological Survey Open-File Report 2012-1157, 53 p. [Also available at http://pubs.usgs.gov/of/2012/1157/.]

Poppe, L.J., Pakevich, V.F., Butman, B., Ackerman, S.D., Danforth, W.W., Foster, D.S., and Blackwood, D.S., 2005, Geological interpretation of bathymetric and backscatter imagery of the seafloor off eastern Cape Cod, Massachusetts: U.S. Geological Survey Open-File Report 2005-1048, 1 DVD-ROM. [Also available at http://woodshole.er.usgs.gov/pubs/of2005-1048/index.htm.]

Schlee, J.S., Folger, D.W., and O'Hara, C.J., 1973, Bottom sediments of the continental shelf off the northeastern United States - Cape Cod to Cape Ann, Massachusetts: U.S. Geological Survey Miscellaneous Geologic Investigations Map I-746, 2 sheets, scale 1:100,000.

Stone, B.D., and Borns, H.W., Jr., 1986, Pleistocene glacial and interglacial stratigraphy of New England, Long Island, and adjacent Georges Bank and Gulf of Maine, in Sibrava, Vladimir, Bowen, D.Q., and Richmond, G.M., eds., Quaternary glaciations in the northern hemisphere: Quaternary Science Reviews, v. 5, p. 39-52.

Stone B.D., and Peper, J.D., 1982, Topographic control of the deglaciation of eastern MassachusettsIce lobation and the marine incursion, in Larson, G.J., and Stone, B.D., eds., Late Wisconsinan glaciation of New England: Dubuque, Iowa, Kendall/Hunt, p. 145-166.

Stone, B.D., Stone, J.R., and McWeeney, L.J., 2004, Where the glacier met the sea-Late Quaternary geology of the northeast coast of Massachusetts from Cape Ann to Salisbury, trip B-3 in Hanson, L.S., ed., Guidebook for field trips from Boston, MA to Saco Bay, ME-New England Intercollegiate Geological Conference, 96th annual meeting, Salem, Mass., 2004, proceedings: Salem, Mass., Salem State College, $25 \mathrm{p}$.

Uchupi, Elazar, Giese, G.S., Aubrey, D.G., and Kim, D.J., 1996, The late Quaternary construction of Cape Cod, Massachusetts - A reconsideration of the W.M. Davis model: Geological Society of America Special Paper, v. 309, 69 p. [Also available at http://specialpapers.gsapubs.org/content/309/1.full.pdf.]

Warner, J.C., Butman, Bradford, and Dalyander, P.S., 2008, Storm-driven sediment transport in Massachusetts Bay: Continental Shelf Research, v. 28, p. 257-282. [Also available at http://dx.doi.org/10.1016/j.csr.2007.08.008.]

Wentworth, C.K., 1922, A scale of grade and class terms for clastic sediments: Journal of Geology, v. 30, p. 377-392.

Zen, E-an, Goldsmith, Richard, Ratcliffe, N.M., Robinson, Peter, and Stanley, R.S., 1983, Bedrock geologic map of Massachusetts: U.S. Geological Survey, 3 sheets, scale 1:250,000. 


\section{Figures}

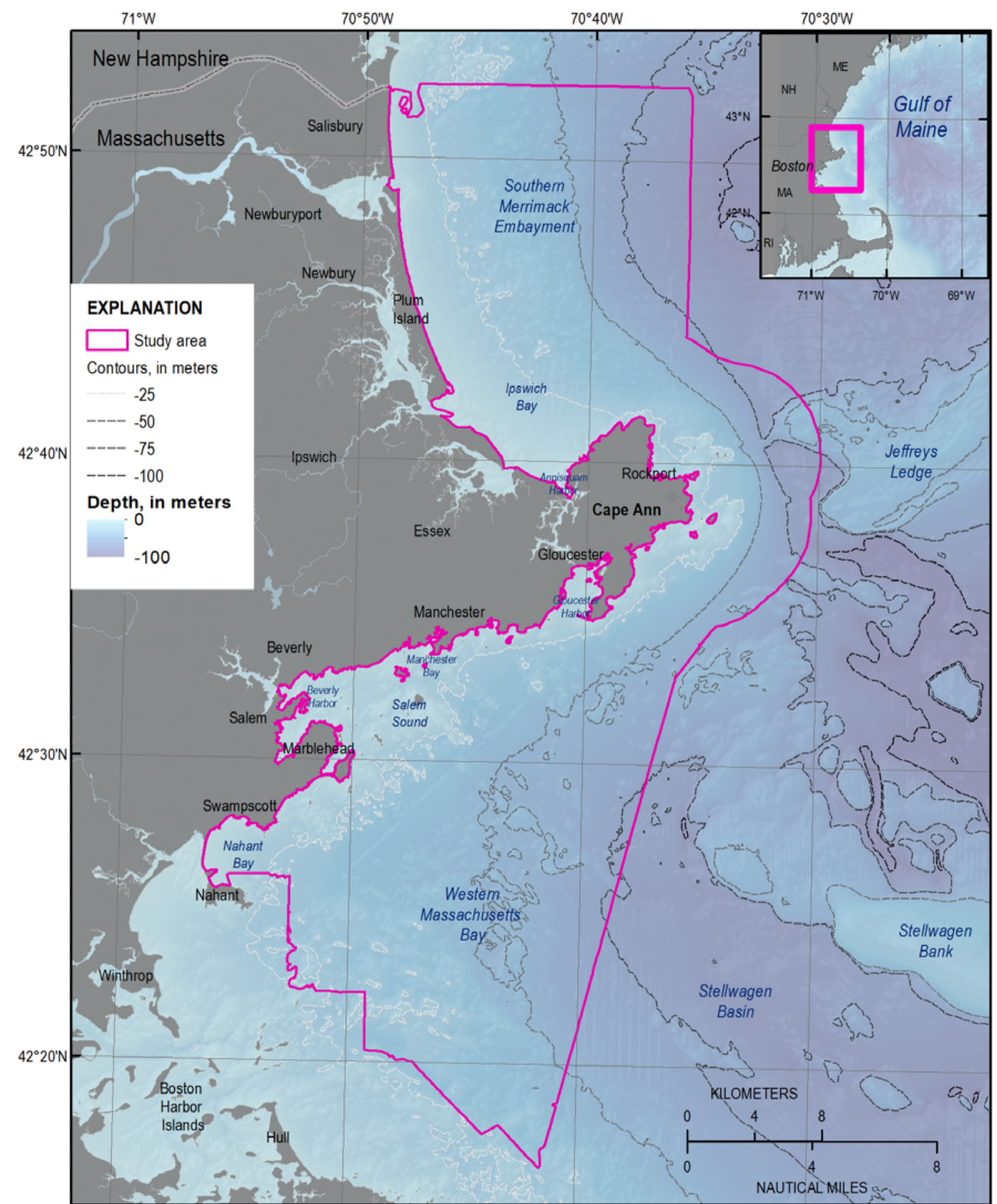

Base from Massachusetts Office of Geographic Information, U.S. Geological Survey, and the National and Oceanic and Atmospheric Adminstration's National Geophysical Data Center.

Universal Transverse Mercator Projection, Zone 19N

Figure 1. Location map of the study area (outlined in pink) that extends from offshore of Hull to Salisbury, Massachusetts, near the New Hampshire border. The outline is the extent of the surficial-sediment texture map and includes western Massachusetts Bay and the southern Merrimack Embayment. 


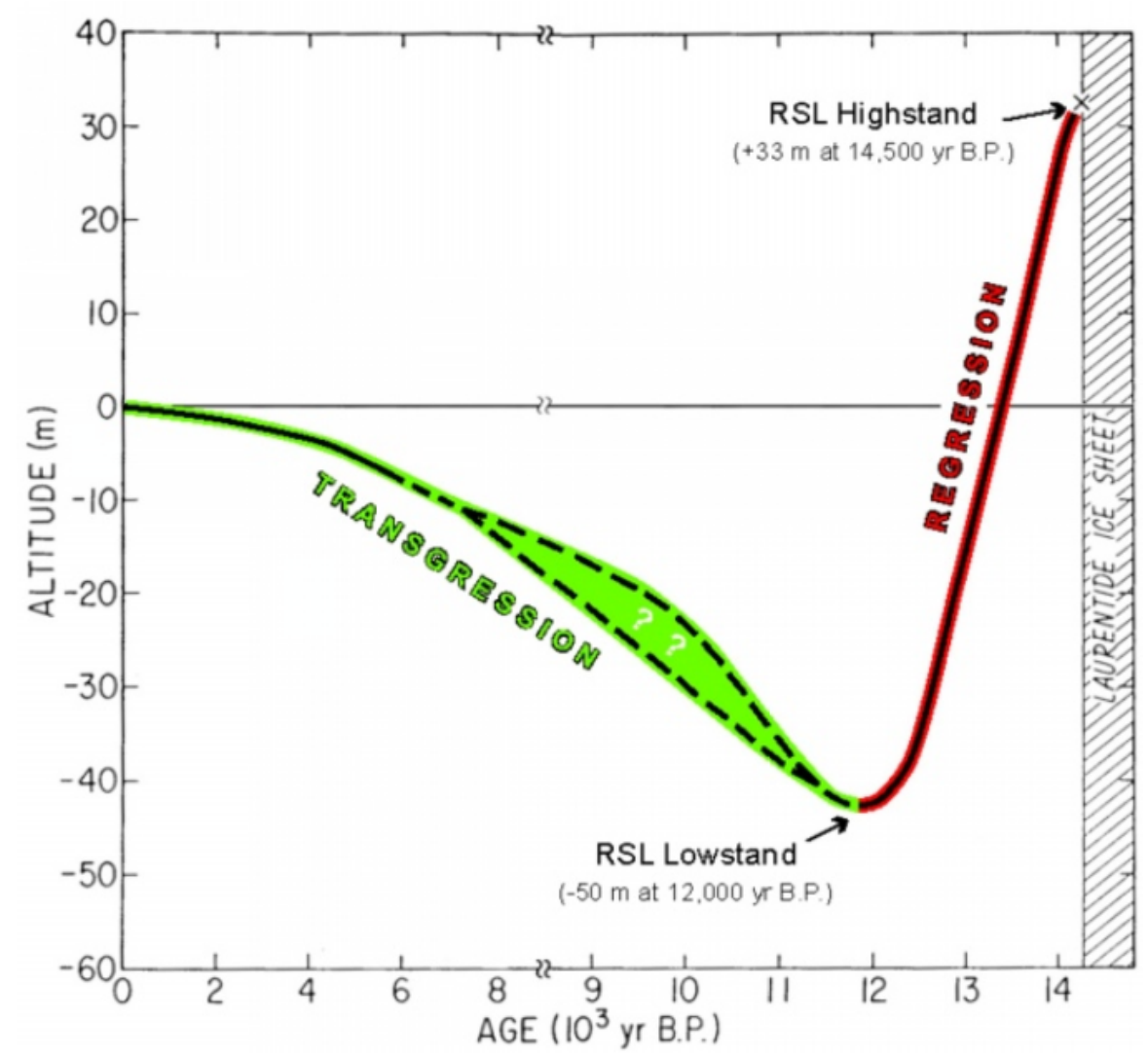

Figure 2. Sea-level curve for the southern Merrimack Embayment from Barnhardt and others (2009), modified after Oldale and others (1993). Following deglaciation, relative sea-level (RSL) fell in northeast Massachusetts in response to ice removal. Near the end of the Pleistocene, about 12,000 years before present (yr B.P.), sea level reached a lowstand of about -50 meters $(\mathrm{m})$ before it began to rise again. Note the age scale changes at 8,000 $\mathrm{yr}$ B.P. 


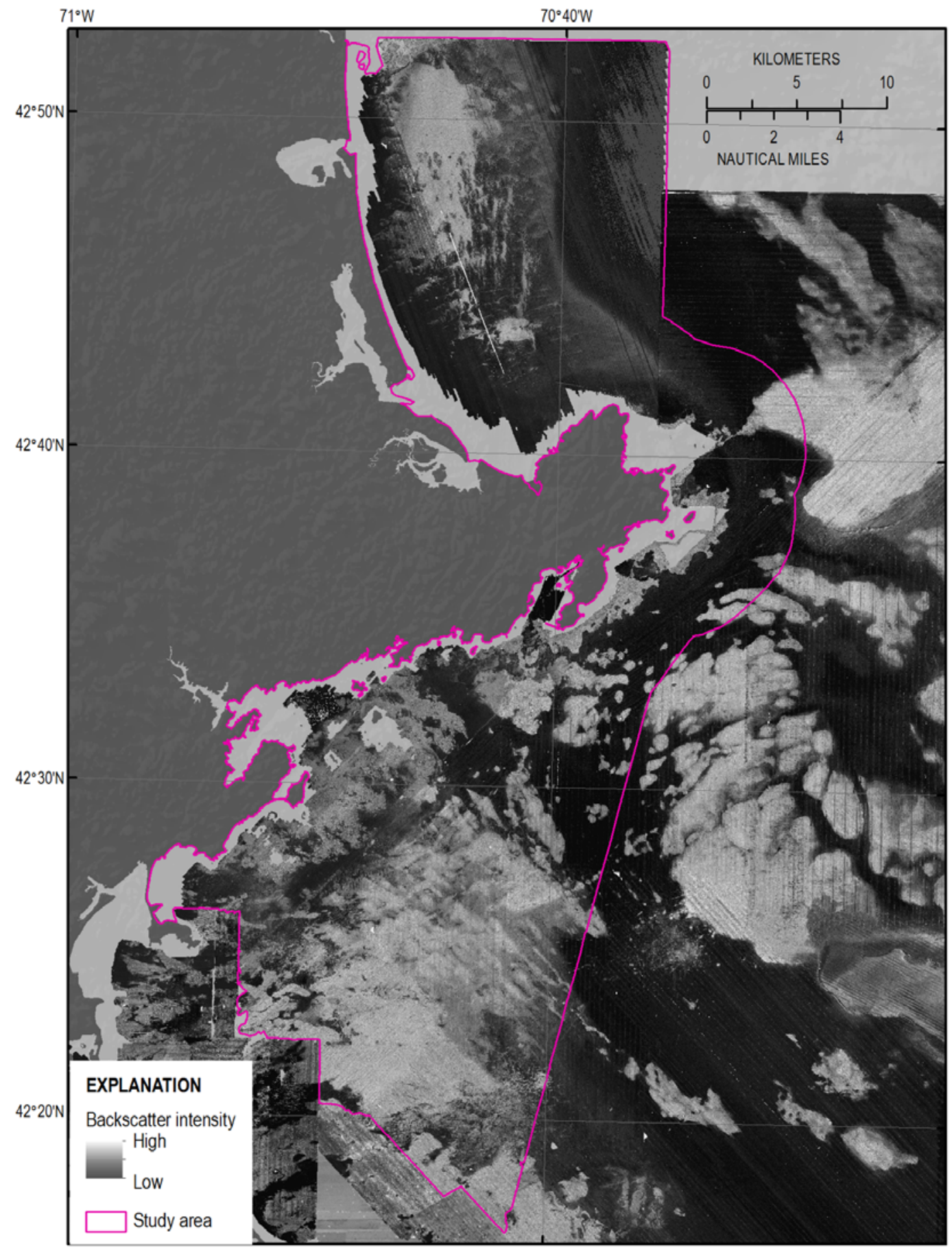

Base from Massachusetts Office of Geographic Information.

Universal Transverse Mercator Projection, Zone 19N

Figure 3. A composite backscatter image of the study area at 10-meter resolution, created from a series of published backscatter images (table 2). Areas of high backscatter intensity (light tones) have strong acoustic reflections and suggest boulders, gravels, and generally coarse sea-floor sediments. Areas of low backscatter intensity (dark tones) have weak acoustic reflections and are generally of finer grained material such as muds and fine sands. Regularly spaced striping is an artifact of the surveys. 


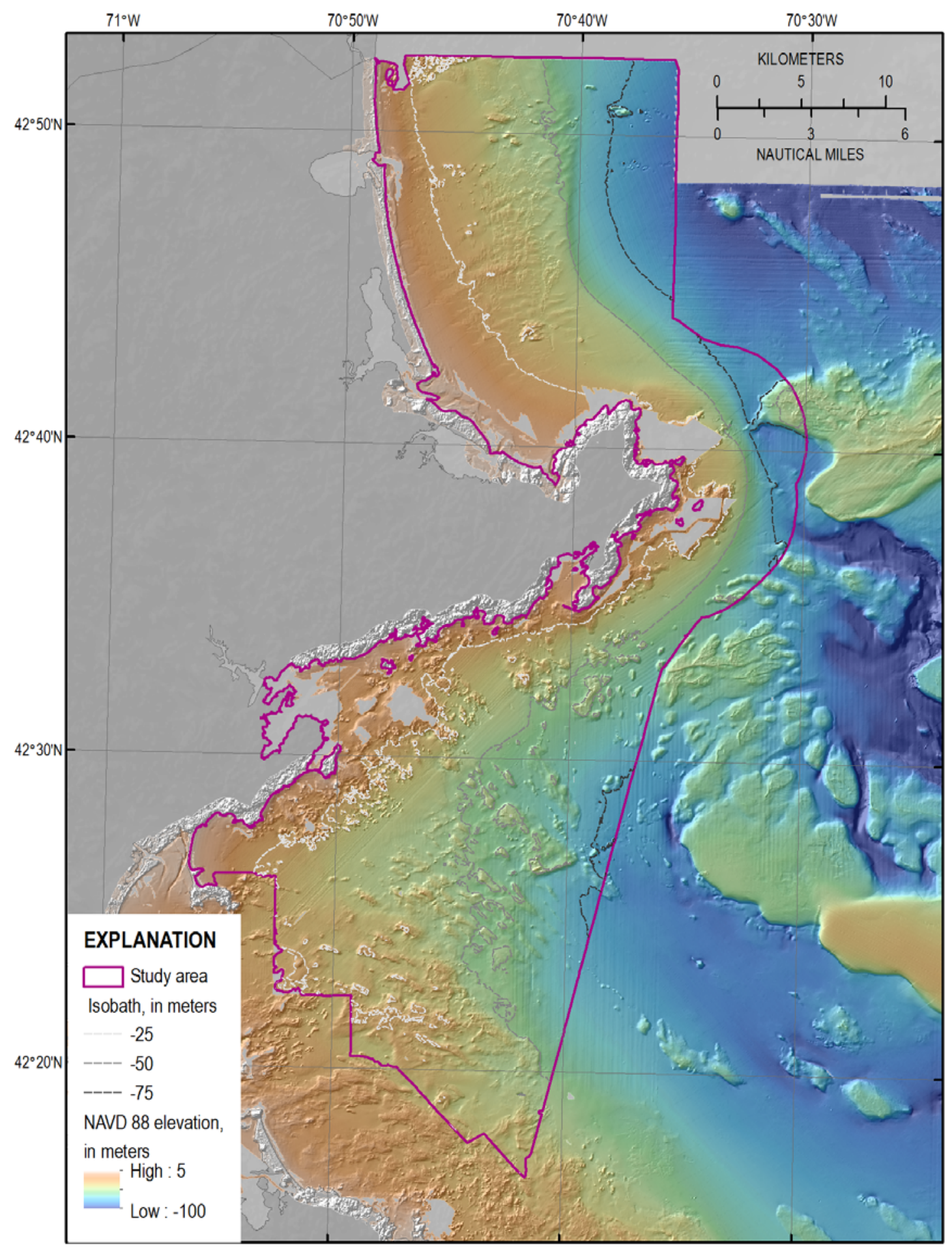

Base from Massachusetts Office of Geographic Information.

Universal Transverse Mercator Projection, Zone 19N

Figure 4. A digital elevation model (DEM), produced from swath-interferometric and multibeam bathymetry and lidar at 30-meter resolution (table 2). High rugosity and high relief are most often associated with rocky areas, whereas smooth, low-relief regions tend to be blanketed by fine-grained sediment deposits. NAVD 88, North American Vertical Datum of 1988. 


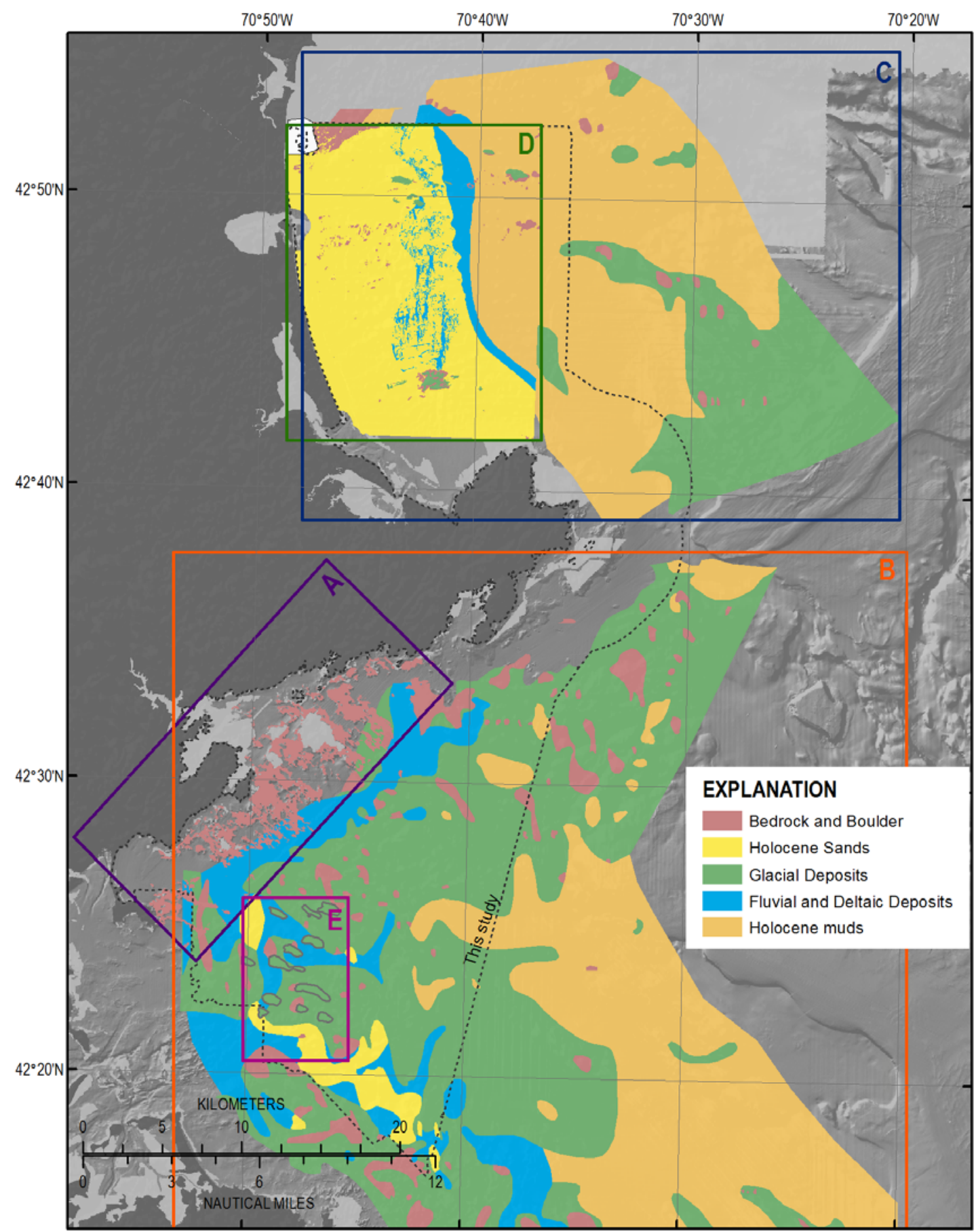

Base from Massachusetts Office of Geographic Information, U.S. Geological Survey, and the National and Oceanic and Atmospheric Adminstration's National Geophysical Data Center. Universal Transverse Mercator Projection, Zone 19N

Figure 5. Generalized geologic map created by combining previously published stratigraphic interpretations within the study area and new interpretation for western Massachusetts Bay. Data are modified from $A$, Barnhardt and others (2006); B, Oldale and Bick (1987); C, Oldale and Wommack (1987); D, Hein and others (2013); and $E$, Oldale and others (1994). The stratigraphic correlation of units in this map is shown in figure 6 . The drumlins identified by Oldale and others (1994) in western Massachusetts Bay are outlined in gray. 


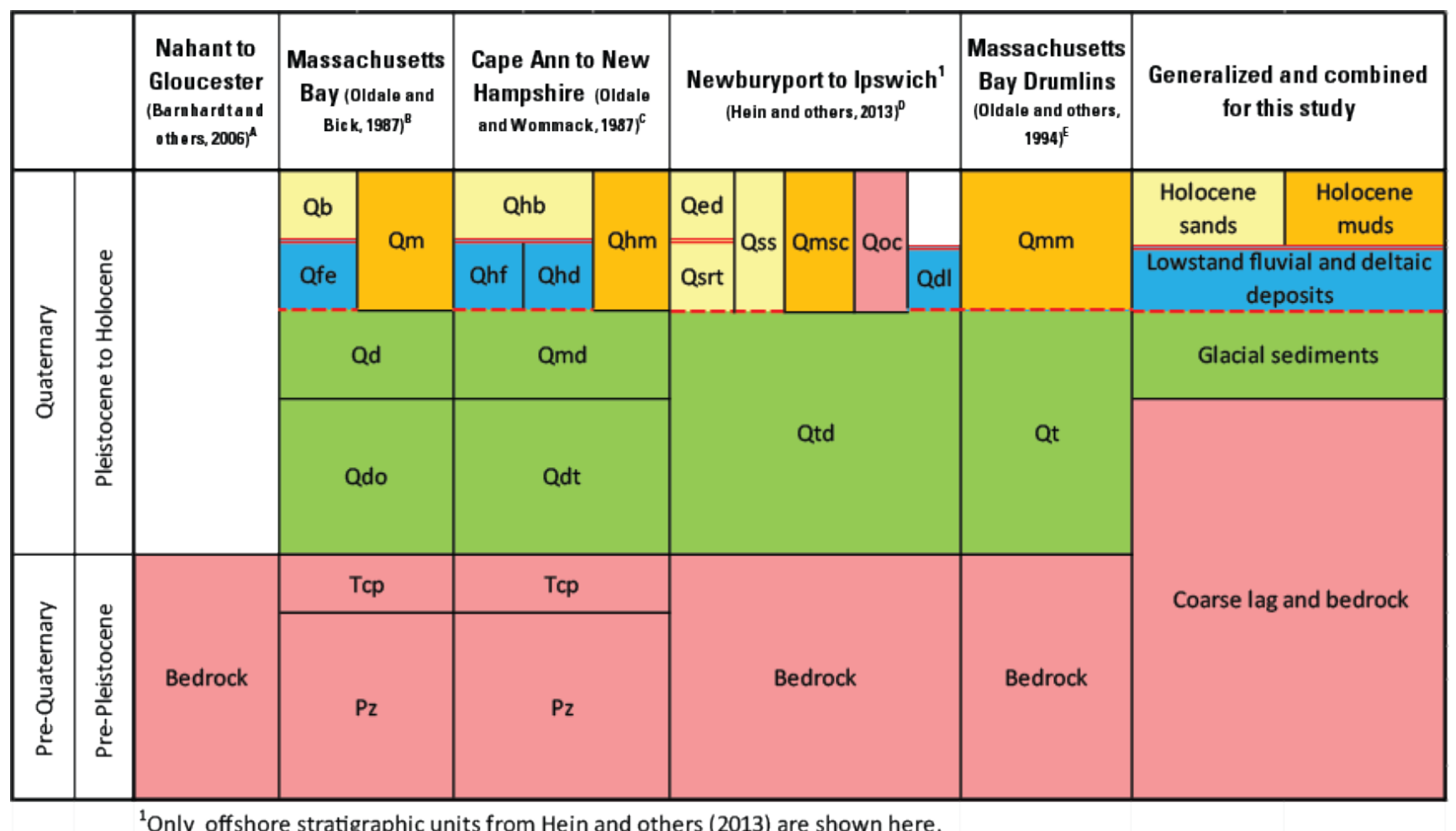

Figure 6. Seismic stratigraphic units interpreted by Oldale and Bick (1987), Oldale and Wommack (1987), and Hein and others (2013). Barnhardt and others (2006) published a sediment thickness map, which was used to identify areas of outcropping bedrock on the inner continental shelf between Nahant and Gloucester, Massachusetts. Transgressive (thick red line) and regressive unconformities (dashed red line) were also identified in several of these studies. The stratigraphic unit names and resolution of these studies differed, but the origin and texture of the deposits can be readily combined into a generalized geologic map (fig. 5) to correlate with sediment textures and physiographic zones presented in this study. $\mathrm{Qb}^{\mathrm{B}}$ and $\mathrm{QhbC}$, Holocene beach and bar deposits; Qss ${ }^{D}$, late Pleistocene to Holocene transgressive sand sheet deposits; Qsit ${ }^{D}$, late Pleistocene to Holocene regressive-transgressive shoreline deposits; QedD, Holocene ebb tidal delta deposits; Qoc ${ }^{D}$, late Pleistocene to Holocene offshore coarse deposits; $\mathrm{Qm}^{\mathrm{B}}, \mathrm{Qhm}^{\mathrm{C}}, \mathrm{Qmm}^{\mathrm{E}}$, and $\mathrm{Qmsc}^{\mathrm{D}}$, late Pleistocene to Holocene offshore marine deposits; Qfe ${ }^{B}$ and QhfC, Holocene fluvial and estuarine deposits; Qhd', Holocene deltaic deposits; QdID, late Pleistocene lowstand delta deposits; $\mathrm{Qd}^{\mathrm{B}}$ and $\mathrm{Qmd} \mathrm{d}^{\mathrm{C}}$, Pleistocene glacial-marine deposits; $\mathrm{Qdo} \mathrm{B}$ and Qdt $\mathrm{C}$, Pleistocene coarse drift deposits; QtdD and QtE, Pleistocene drumlin till deposits; $\mathrm{Tcp}^{\mathrm{B}, \mathrm{C}}$, Tertiary and late Cretaceous coastal plain deposits; $\mathrm{PZ}^{\mathrm{B}, \mathrm{C}}$, Triassic and older bedrock. 


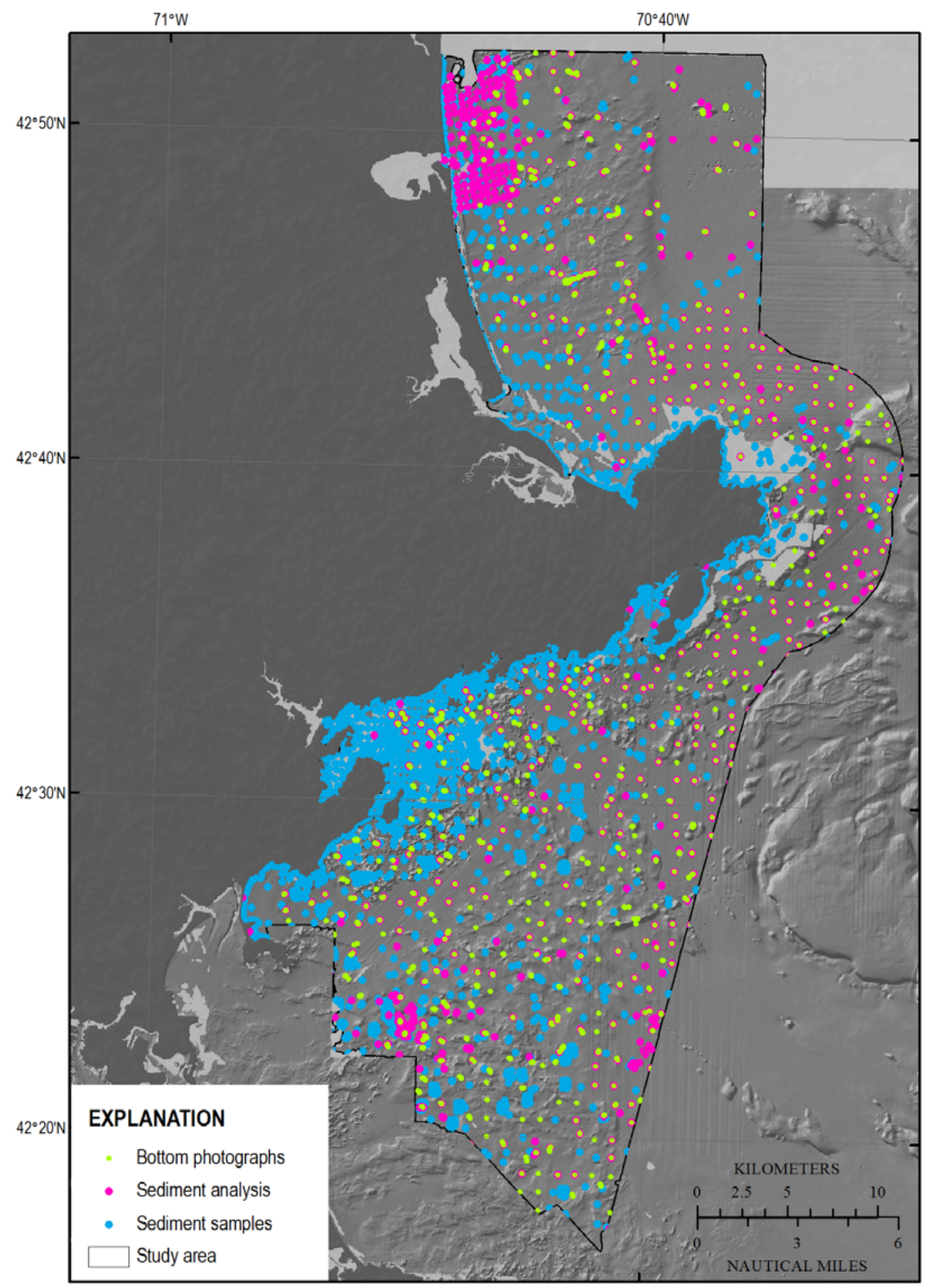

Base from Massachusetts Office of Geographic Information.

Universal Transverse Mercator Projection, Zone 19N

Figure 7. Bottom photographs (Barnhardt and others, 2006, 2009; Gutierrez and others, 2000; green dots) and sediment samples collected within the study area and used to aid interpretations. Sediment samples with laboratory analysis are shown as magenta dots, while blue dots are visual descriptions (Ford and Voss, 2010; McMullen and others, 2011; Emily Huntley, Massachusetts Office of Coastal Zone Management, unpub. data, 2012). 


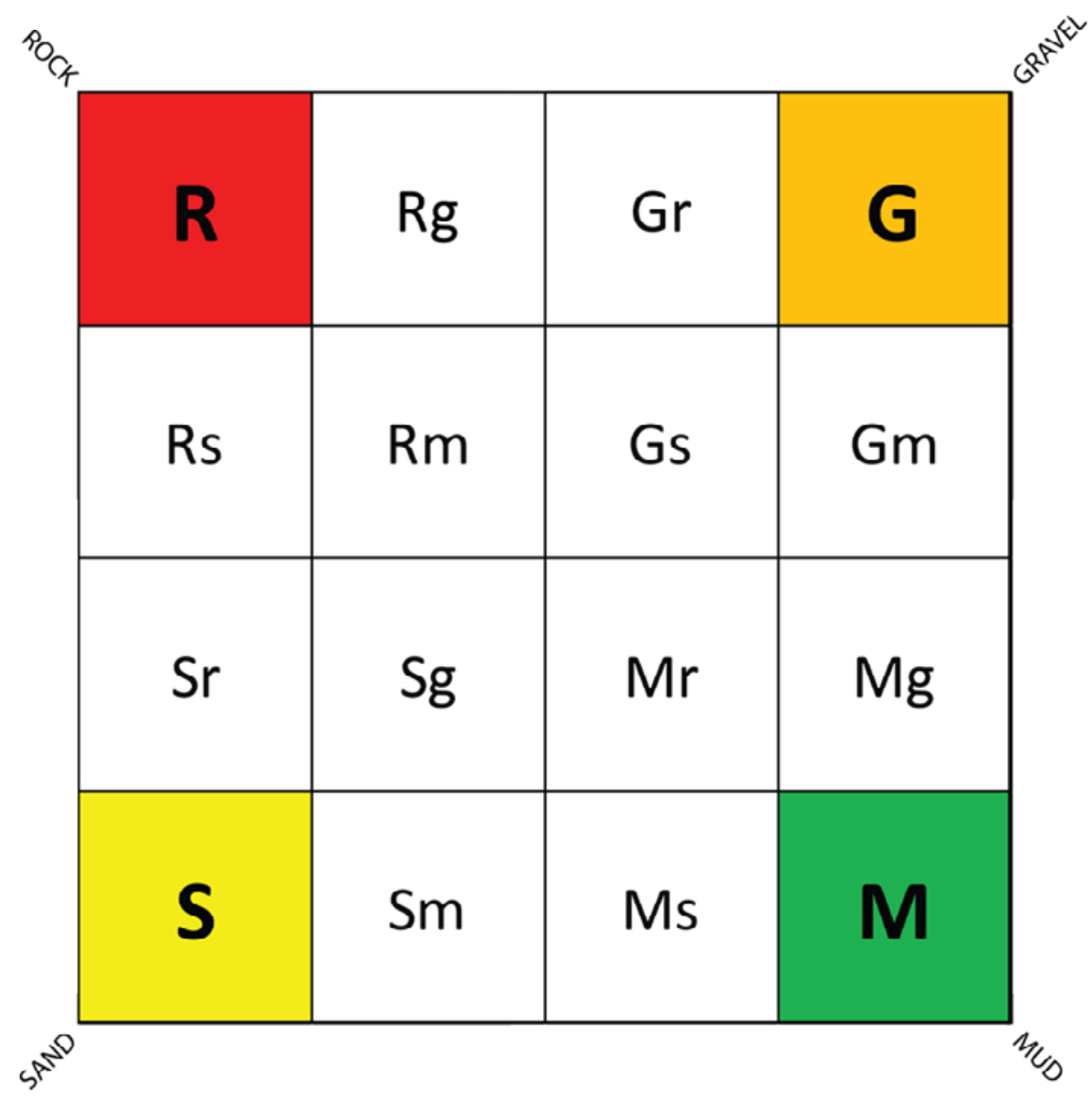

Figure 8. Barnhardt and others (1998) bottom-type classification based on four basic sediment units: rock (R), gravel $(G)$, sand $(S)$, and mud $(M)$. If one of the basic sediment units represents more than 90 percent of the texture, only its uppercase letter is used. Twelve additional two-part units represent combinations of the four basic units, where the primary texture (greater than 50 percent) is given an uppercase letter and the secondary texture (less than 50 percent) is given a lowercase letter. 


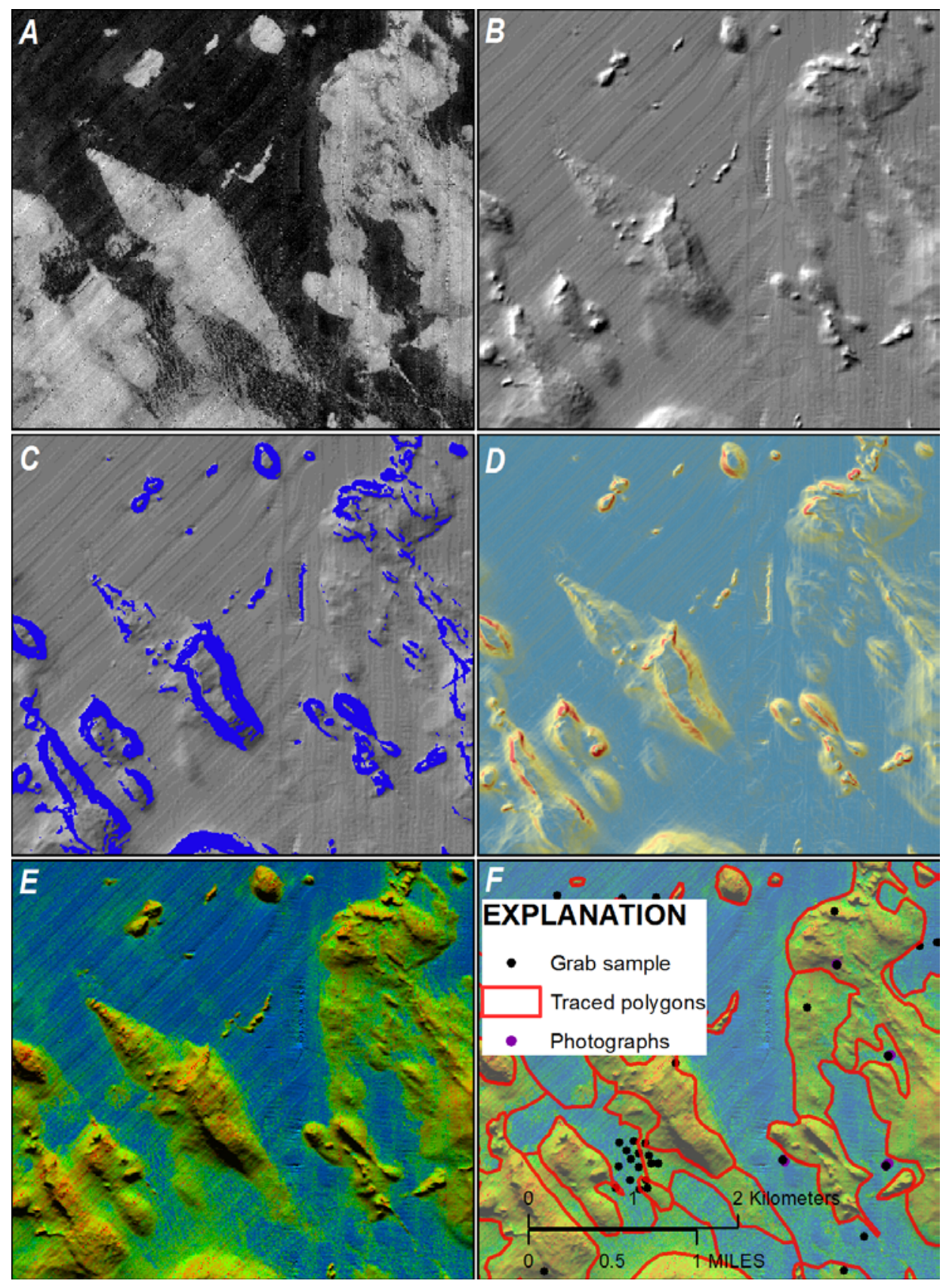

Figure 9. Sediment texture polygons were created in ArcGIS by using A, backscatter data, where areas of high backscatter intensity (light tones) have strong acoustic reflections and suggest boulders, gravels, and generally coarse sea-floor sediments, and areas of low backscatter intensity (dark tones) have weak acoustic reflections and generally are characterized by fine-grained material such as muds and fine sands; $B$, hillshaded relief imagery, which creates a three-dimensional effect to provide a sense of topographic relief; $C$, rugosity, where blue polygons outline areas of variation or frequent amplitude changes in topography, often referred to as surface roughness; $D$, slope, where warm colors represent steeper areas of the map and cool colors represent flatter areas; and $E$, pseudocolored multibeam backscatter intensity (Butman and others, 2007), which combines backscatter and hillshaded relief. Each data type can provide useful information in a given area when defining texture boundaries. $F$, Bottom samples and photographs are used to assign a sediment texture within each polygon drawn on the basis of geophysical data and derivatives such as $B-E$. 


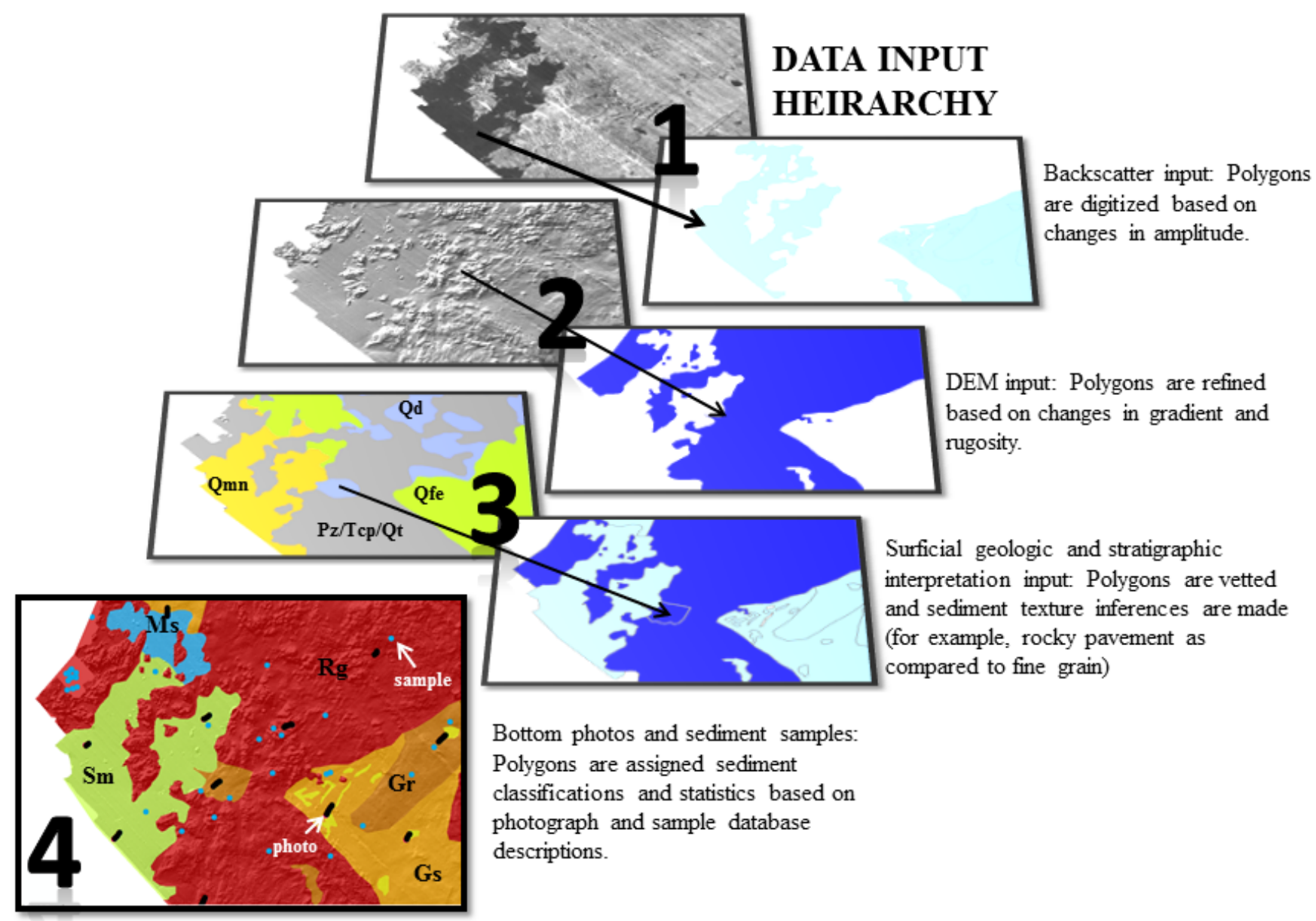

Figure 10. Sediment texture and distribution data were mapped qualitatively in ArcGIS by using a hierarchical methodology. Backscatter data were the first input, followed by bathymetry, surficial geologic and shallow stratigraphic interpretations, and photograph and sample databases. From Pendleton and others (2013). DEM, digital elevation model. 


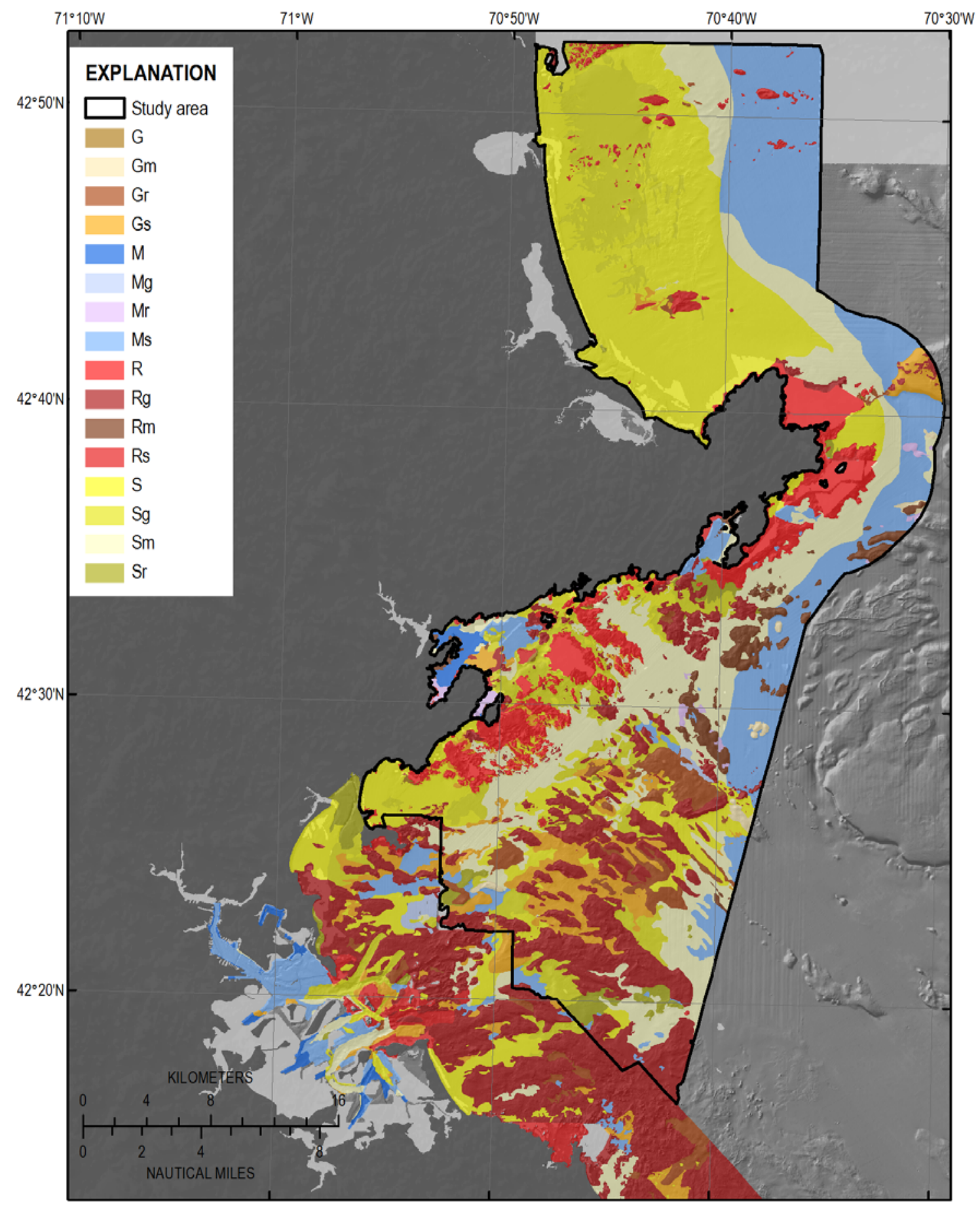

Base from Massachusetts Office of Geographic Information.

Universal Transverse Mercator Projection, Zone 19N

Figure 11. The distribution of sediment textures within the study area from Nahant, Massachusetts, to New Hampshire. The bottom-type classification is from Barnhardt and others (1998) and is based on 16 sediment classes. The classification is based on four sediment units that include gravel $(G)$, mud $(M)$, rock $(R)$, and sand $(S)$ (fig. 8). If the texture is greater than 90 percent, it is labeled with a single letter. If the composition of one component is less than 90 percent, it is labeled with two letters, where the first letter is the primary sediment unit (more than 50 percent) and the second letter is the secondary sediment unit (less than 50 percent). 

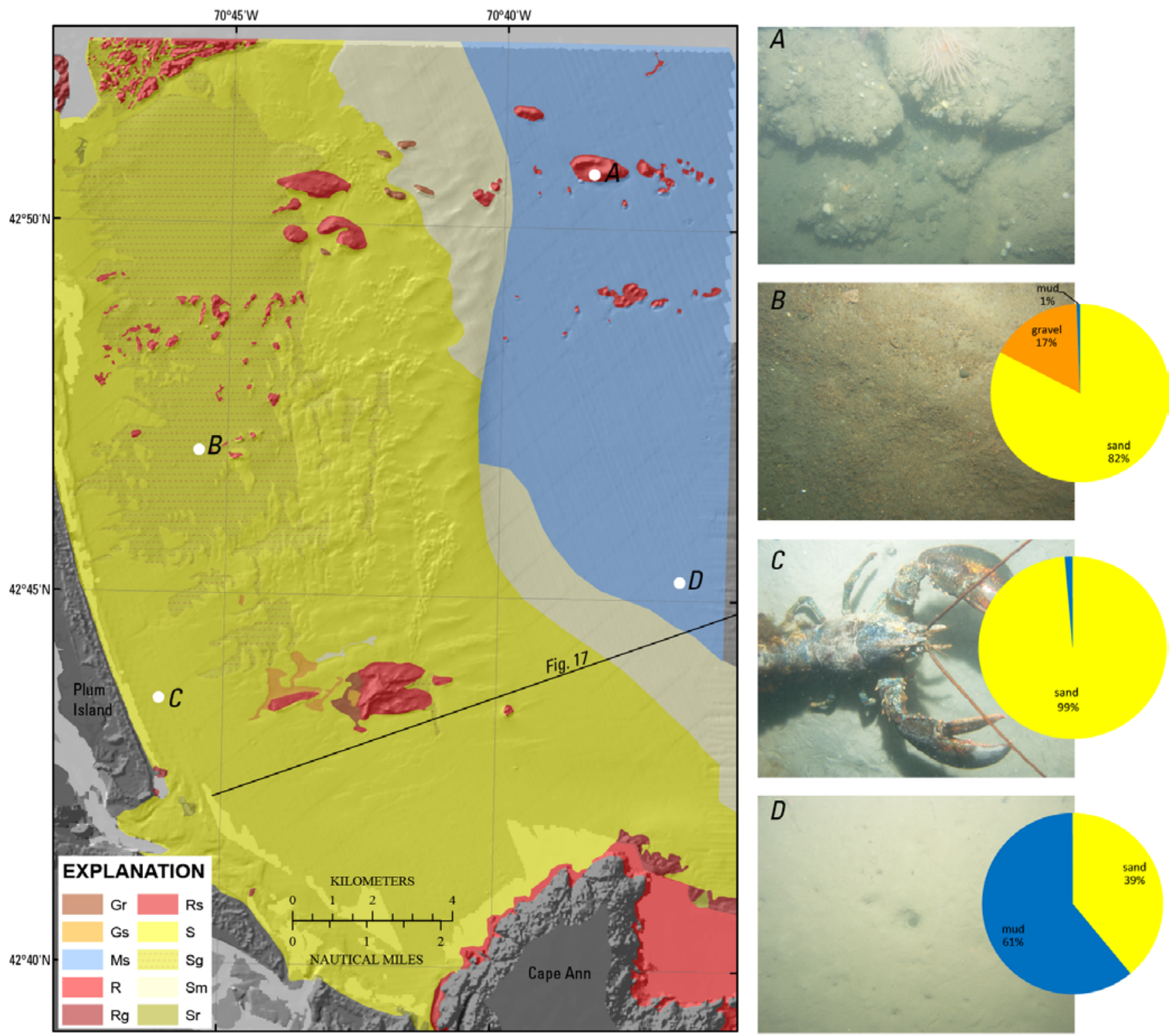

Base from Massachusetts Office of Geographic Information.

Universal Transverse Mercator Projection, Zone 19N

Figure 12. Inner continental shelf sediment textures between Cape Ann and New Hampshire with bottom photographs $A-D$ showing sediment texture as defined in select locations. Grain-size statistics are plotted as pie charts showing the relative percentages of gravel, sand, and mud. A, A photograph of the sea floor within an area classified as rock and gravel $(\mathrm{Rg})$. No sample was recovered in this area because of large particle size. $B, A$ photograph of the sea floor within an area classified as primarily sand with some gravel (Sg). C, A photograph from a section of sea floor classified as primarily sand (S). D, A photograph from a section of the sea floor classified as primarily mud with some sand. The viewing frame for photographs $A-D$ is approximately 50 centimeters, and the locations of the photographs are shown as white dots on the sediment texture map. The location of the seismicreflection profile in figure 17 is also indicated by the black line. Sediment classes are shown in figure 8. \%, percent. 


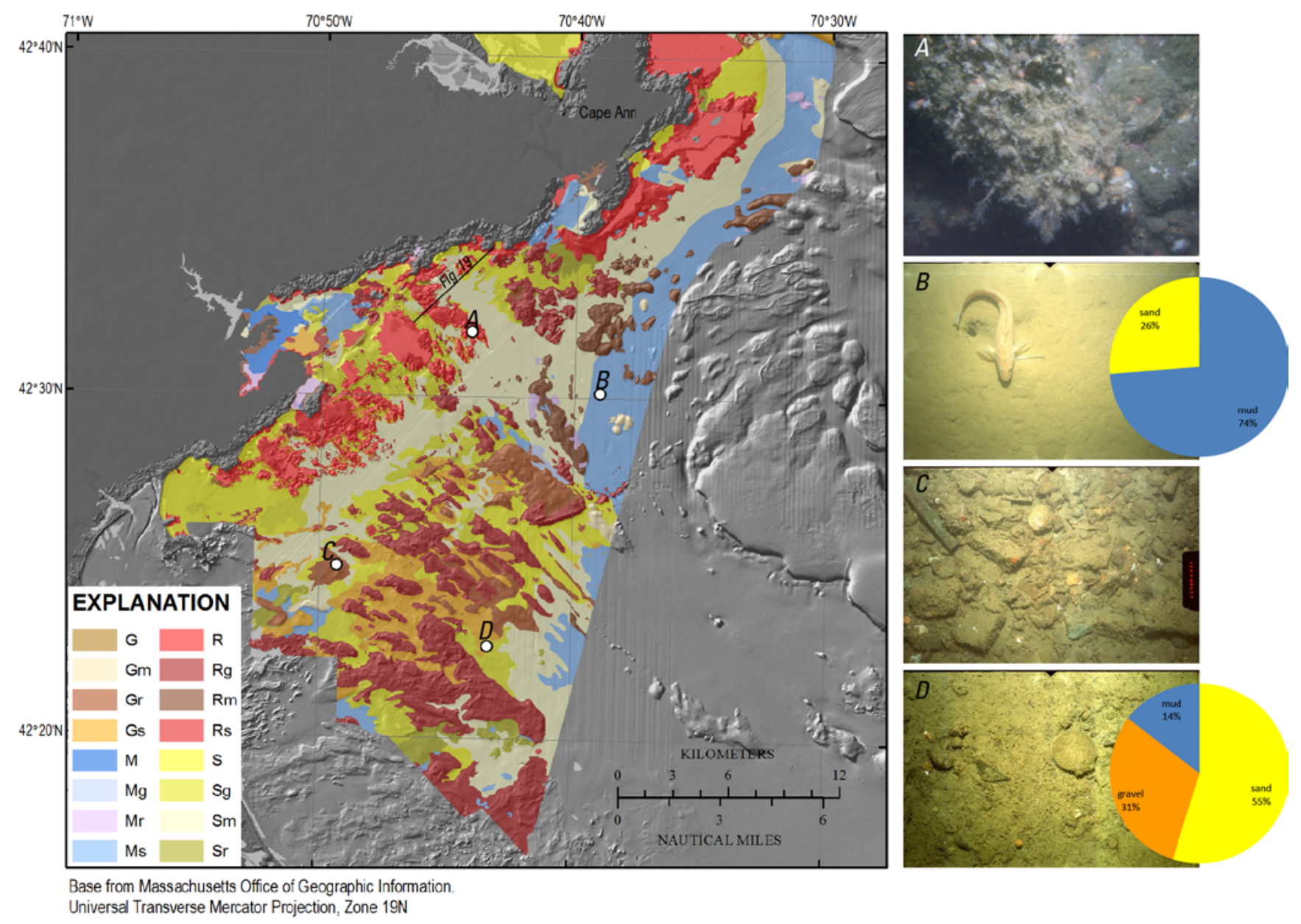

Figure 13. Inner continental shelf sediment textures within western Massachusetts Bay with bottom photographs $A-D$ showing sediment texture as it is defined in select locations. Grain-size statistics are plotted as pie charts showing the relative percentages of gravel, sand, and mud. A, A photograph of the sea floor within an area classified as rock (R). No sample was recovered in this area because of large particle size. $B, A$ photograph of a section of sea floor classified as primarily mud with sand (Ms). C, A photograph from a section of sea floor classified as primarily gravel with rock (Gr). No sample was recovered in this area because of large particle size. $D$, A photograph from a section of the sea floor classified as primarily sand and gravel $(\mathrm{Sg})$ with some mud. This photograph is located near the boundary of a $\mathrm{Sg}$ and $\mathrm{Gs}$ texture transition. The viewing frame for photographs $A-D$ is approximately 50 centimeters, and the locations of the photographs are shown as white dots on the sediment texture map. The location of the seismic-reflection profile from figure 19 is indicated by the black line. Sediment classes are shown in figure $8 . \%$, percent. 


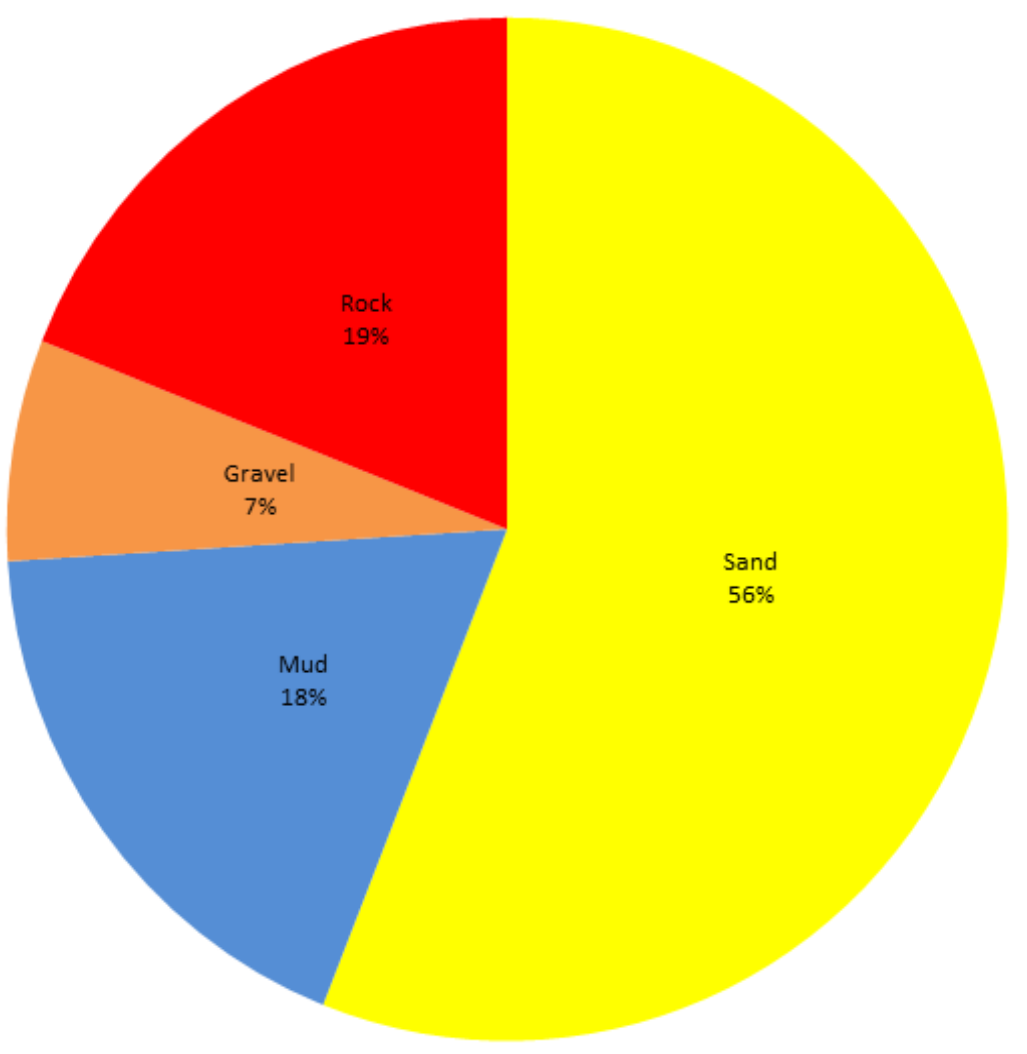

Figure 14. Pie chart showing the percentage of each primary sediment unit (texture greater than 50 percent) within the study area. \%, percent. 


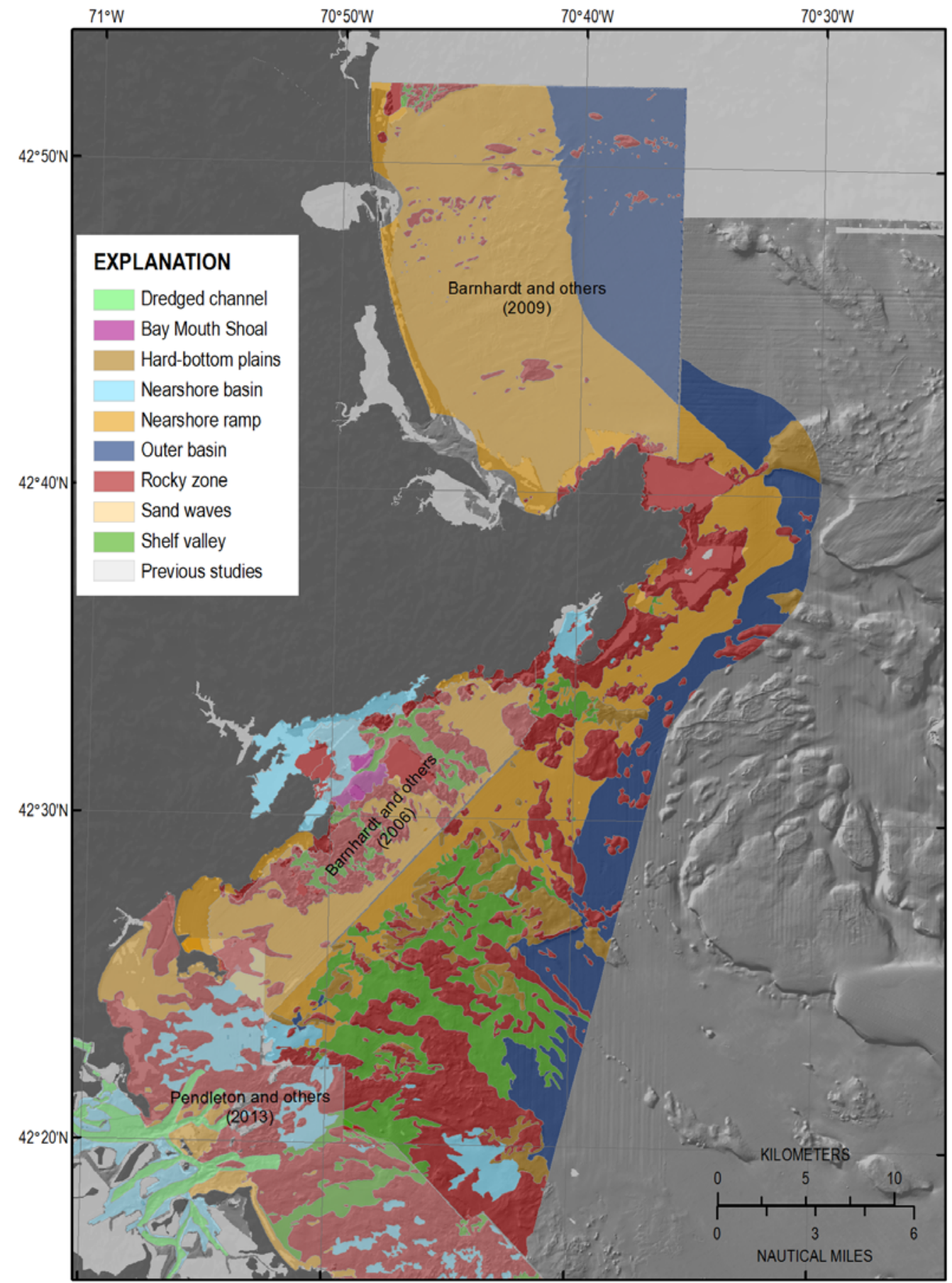

Base from Massachusetts Office of Geographic Information.

Universal Transverse Mercator Projection, Zone 19N

Figure 15. The distribution of physiographic zones within the study area from Nahant to Salisbury, including western Massachusetts Bay. The physiographic zone classification is based on Kelley and others (1996) and builds on interpretations developed by Butman and others (2003a,b,c, 2004) and Knebel and Circe (1995), and the zones are delineated on the basis of sea-floor morphology and the dominant texture of surficial material. Areas interpreted by Barnhardt and others $(2006,2009)$ and Pendleton and others $(2013)$ are shown for regional context and have a slight gray transparency. 


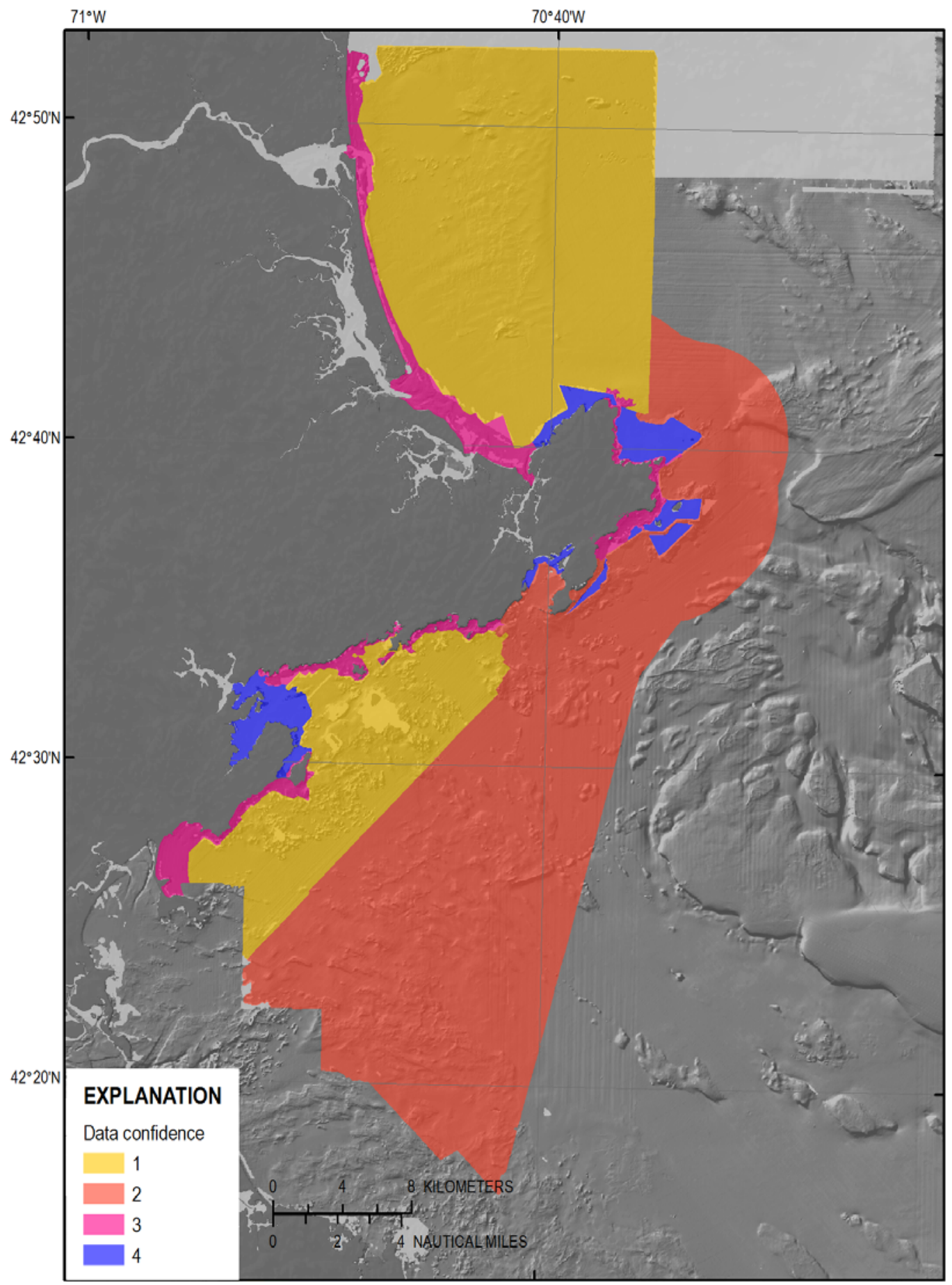

Figure 16. Sediment texture regions in the study area and confidence values for data interpretation. Sediment texture polygons are assigned a confidence value from one (highest confidence) to four (lowest) on the basis of the resolution of geophysical data and the number of input data sources. 

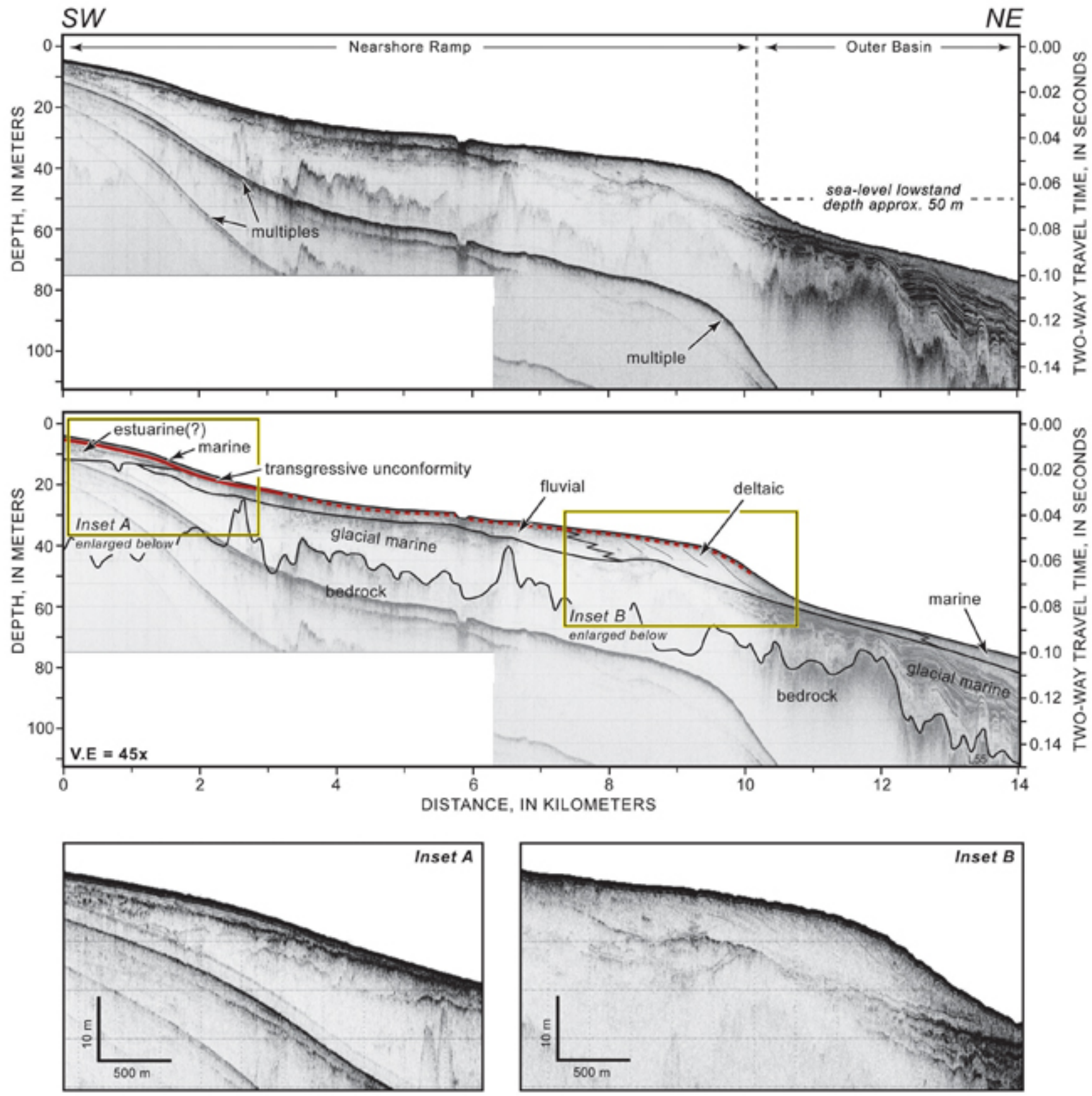

Figure 17. A chirp seismic reflection profile across the inner shelf from near the southern end of Plum Island, Massachusetts, to approximately 70 meters $(\mathrm{m})$ water depth (see fig. 12 for profile location). The top panel is the uninterpreted profile, and the middle panel is interpreted to show geologic units. Fluvial and deltaic deposits overlie glacial-marine sediments, which overlie bedrock. The Holocene sand sheet is separated from fluvial sediments by a transgressive unconformity (red line, where the solid line is interpreted and dashed red is inferred). SW, southwest; NE, northeast; V.E., vertical exaggeration. Figure from Barnhardt and others (2009). 

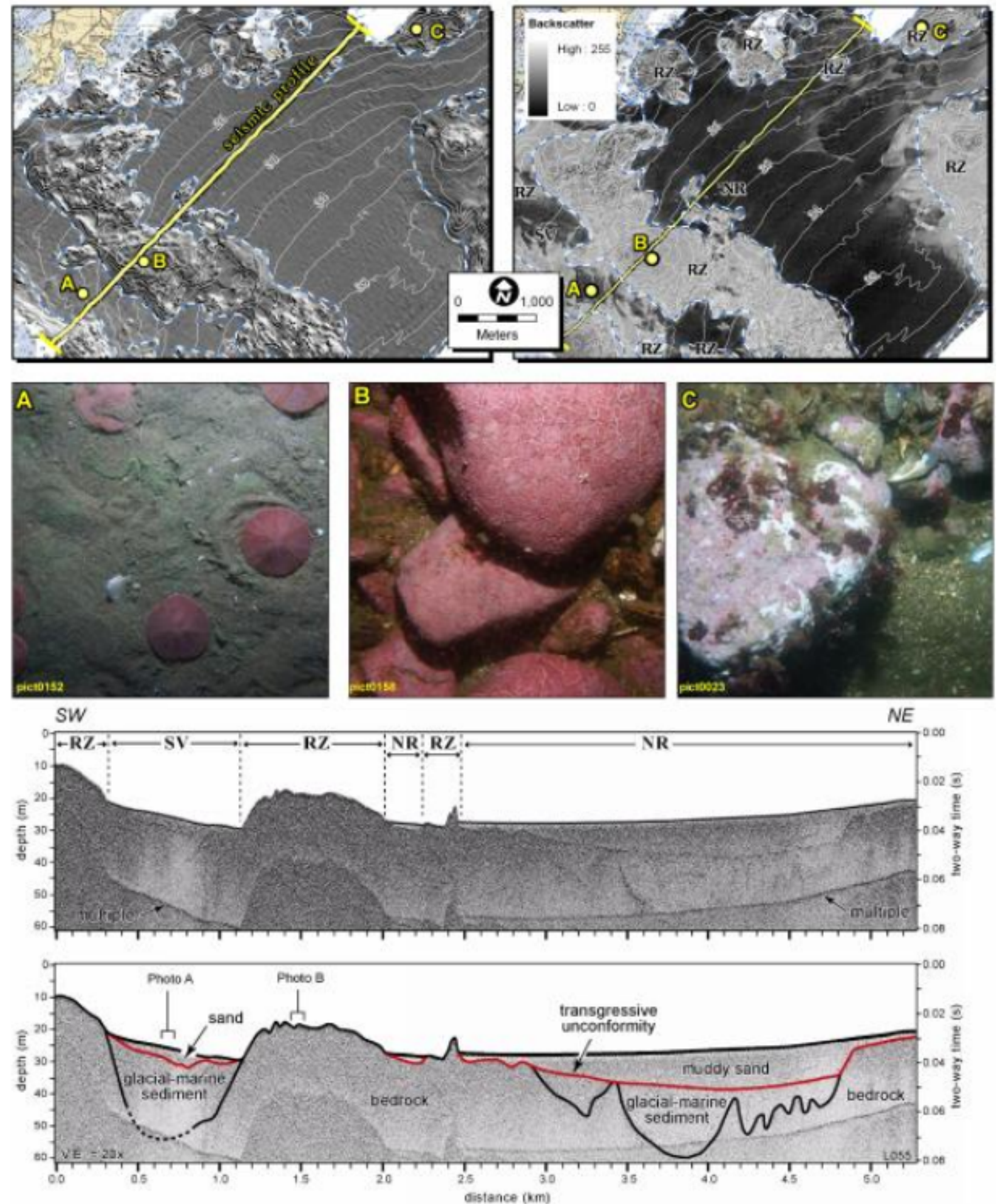

Figure 18. Figure showing bathymetry (upper left), backscatter (upper right) with physiographic zone boundaries, and bottom photographs (center) along a seismic reflection profile (bottom two panels). Yellow line on bathymetry panel is the location of the seismic profile (also shown in fig. 13). Shelf valleys formed often between bedrock highs during the lowstand and unconformably overlie glacial-marine deposits. RZ, rocky zone; SV, shelf valley; NR, nearshore ramp; SW, southwest; NE, northeast; m, meters; s, seconds; km, kilometers. From Barnhardt and others (2006). 


\section{Appendix 1. Geospatial Data}

[Available as part of the HTML report at http://pubs.usgs.gov/of/2015/1153/html/ofr20151153_GIS_catalog.html.] 
For more information concerning this report, contact: Director, Woods Hole Coastal and Marine Science Center

U.S. Geological Survey

384 Woods Hole Road

Quissett Campus

Woods Hole, MA 02543-1598

WHSC_science_director@usgs.gov

508-548-8700 or 508-457-2200

or visit our Web site at:

http://woodshole.er.usgs.gov/

Publishing support by:

The Pembroke Publishing Service Center. 
